[VOL. XXVIII, NO. 1

\title{
MARKETING PRODUCTION FROM JOINT PROPERTY: THE PAST, THE PRESENT AND THE FUTURE
}

\section{J. JAY PARK*}

\begin{abstract}
Deregulation in the gas industry has forced Alberta producers to meet increased competition with an aggressive new marketing philosophy. This new philosophy has caused disharmony in a supply market which has traditionally included co-operative joint ventures. Difficulties arise when one joint-operator takes on the full burden of marketing. The author examines the agreements and procedures which have regulated joint operators, and suggests changes to accommodate these new pressures.
\end{abstract}

\section{INTRODUCTION}

The business of marketing oil and natural gas has changed a great deal in the past few years, and promises to continue to evolve at a rapid pace in the coming years. Yesterday's regulated environment fostered an oil and gas industry that focused on exploration and development of oil and gas reserves without the need to expend efforts on marketing. Today's situation is very different, and marketing has become a critical part of managing an oil and gas company. Just as changes in the business environment have placed new stresses on energy industry executives, new stresses have been placed on the agreements which govern marketing operations of gas properties.

The purpose of this paper is firstly to examine and interpret the provisions of the Canadian Association of Petroleum Landmen (CAPL) Operating Procedures in light of some of the fact situations that are becoming more common in today's new environment. Special attention will be given to some of the difficult questions of interpretation which result from the language used in Article VI of the CAPL Operating Procedures. It is not possible to provide answers to all of the questions and problems that arise because there is extremely little Canadian case law on the subject, and because the CAPL Operating Procedures contain some uncertain provisions. In fact, in many respects it seems the CAPL Operating Procedures were written to deal with oil marketing rather than gas marketing. For this reason, most of the issues discussed below relate to problems associated with marketing gas from joint interest properties. By focusing on the fact situations and the interpretation problems that arise, the need for new provisions governing the sale of oil and gas from joint interest properties should become apparent.

Second, the options will be reviewed for changing the marketing arrangements among producers of jointly owned property. This will include a review of the most recent draft of Article VI proposed for inclusion in the next version of the CAPL Operating Procedure. Also, the option of gas balancing will be reviewed with particular emphasis on the issues it raises among producers of jointly owned property. Third, certain issues will be examined which relate to joint facilities ownership under the current and proposed CAPL Operating Procedure.

\section{THE PAST}

Article VI of the CAPL Operating Procedure was prepared in a different gas marketing environment. Gas purchase contracts in the 1960's and 1970's were

* Partner with Macleod Dixon, Barristers and Solicitors, Calgary. 
usually for terms of 15 years or more in order to justify the investment costs associated with gathering, transportation and processing. Gas purchasers would buy all of the gas from all of the producers in a field. Rates of "take" were typically based on the underlying reserves dedicated to the contract, and supplementary sales were prohibited. Prices, while not always regulated, were relatively uniform throughout the industry. Moreover, the philosophy underlying the Operating Procedure was that the Operator, typically a major company, was responsible for marketing the product. This philosophy did not cause any serious business problems for the Operator because of the nature of the gas marketing environment, particularly, the practice of gas purchasers buying all of the production from a field.

\section{THE PRESENT}

Today's environment differs markedly from that which existed during the previous decade. Short-term gas purchase contracts are more common. Gas purchasers no longer acquire all of the gas from a particular field. They are prepared to enter into a contract with one producer, frequently without dedication of specified reserves. The contracts are often "deliverability" or best-efforts contracts. Today's current oversupply situation has led to considerable differentiation in the prices available to producers. Currently there is more than a $100 \%$ difference between the lowest prices and highest prices at which gas is being sold in Canada.

These new business circumstances are complemented by a change in the philosophy of many producers, particularly those with marketing expertise. Producers who have a gas contract, now consider that contract to be a corporate asset which they are not prepared to share with other producers. Producers no longer consider it to be their obligation to market the production of their partners. If they are prepared to do so, they would prefer to sell their partners' gas under low price contracts.

New circumstances and a new philosophy - it is easy to see why operating agreements written in the seventies cause problems in the current environment. This is a compelling reason for preparing new agreements to govern the sale of oil and gas from joint interest properties, and for giving some thought to the whole approach which underlies the CAPL Operating Procedure.

\section{THE LAW REGARDING CO-TENANCY}

Before examining the provisions of Article VI of the CAPL Operating Procedure, it would be worthwhile to examine the law applicable to co-ownership of property.

Joint ownership of property where the co-owners are simultaneously entitled to the use and enjoyment of the property is commonly called co-tenancy. Co-tenancy is the usual manner in which oil and gas properties are held. A co-tenant cannot lay claim to any part of the property to the exclusion of other co-owners.'

In addition to the common law, there is relevant statutory law which affects the relationship between co-tenants. The Alberta Judicature Act (R.S.A. 1980, c. J-1)

1. Jacobs v. Seward (1872), 4 C.P. 328, 41 L.J.C.P. 221, cited with approval in Lehman v. Hunter (1939), 13 M.P.R. 553 (N.B.). 
incorporates into Alberta law all of the laws applicable in England in 1870. The Statute of Westminster((U.K.), 1285, 13 Edward I., c. 22.) provides that a co-tenant is liable to his co-tenant for waste. Section 27 of the Statute of 4 Anne (An Act for the Amendment of the Law and the Better Advancement of Justice (U.K.) 1705, 4 Anne c. 16.) provided that:

Actions of Account shall and may be brought and maintained . . . by one joint tenant and tenant in common ... against the other as bailiff for receiving more than comes to his just share or proportion ... .

The interpretation given by English courts to the above cited provision is, that a co-tenant who receives a third party payment of any kind, in excess of his proportionate share according to his interest in the common property, must account for the excess to his co-tenant. ${ }^{2}$

The right of one co-tenant to drill for, and remove, oil and gas from common property, without the consent of his co-tenant, depends upon whether or not the appropriate jurisdiction regards the extraction as waste. The view of the American courts in the various producing states differs on this point. ${ }^{3}$ However, the consensus among oil and gas lawyers is that Canadian courts (which have never ruled on this question) would follow the majority of the U.S. jurisdictions in concluding that the production of oil and gas is not waste. Therefore, a co-owner may produce the property without the consent of the other co-owner, but would be obliged to account to the non-consenting co-owner for his proportionate share of the proceeds of production. ${ }^{4}$

\section{CAPL ARTICLE VI}

The CAPL Operating Procedures confirm by agreement the interpretation of the law discussed above. Article VI of the 1981 CAPL Operating Procedure reads as follows:

OWNERSHIP AND DISPOSITION OF PRODUCTION

601 EACH PARTY TO OWN AND TAKE ITS SHARE - Each of the parties shall own its proportionate share of the petroleum substances produced from wells operated for the joint account and shall have the right, at its own expense, to take in kind and separately dispose of its proportionate share of production exclusive of the production which may be used by the Operator in developing and producing operations and of production unavoidably lost.

2. Henderson v. Eason (1851), 17 Q.B. 701, 117 E.R. 1451; Spelman v. Spelman (1944), 2 D.L.R. 74, [1944] 1 W.W.R. 691, 59 B.C.R. 511 (C.A.).

3. The generally prevailing rule is that extraction of oil and gas from land is not waste, but rather is a natural use of the land. This rule is accepted in all U.S. producing states except West Virginia, Illinois and Louisiana. In those states, extraction of oil and gas is waster and a co-tenant cannot take oil and gas from joint property without the consent of his co-tenants.

4. For further discussion of co-tenancy matters in relation to oil and gas, see R.C. Muir, "Split Sales of Gas" (1971) 9 Alta. L. Rev. 496; M.M. Olisa, "Legal Problems Arising Out of Co-ownership of Oil and Gas Leasehold Estate and Facilities" (1970) 8 Alta. L. Rev. 177; J.J. Park, "Developments in Natural Gas Purchase Contracts" (1984) 22 Alta. L. Rev. 43; for United States commentary, see R.B. Fell, "Marketing of Production from Properties Subject to Operating Agreements" (1982) 33 Inst. on Oil and Gas Law \& Tax'n 115; J.C. La Grone, "Natural Gas Contracting in the '80's" (1981) 32 Inst. on Oil and Gas Law \& Tax'n 25; K. Ellis, "The Production of Gas from Joint Interest Properties" (1970) 21 Inst. on Oil and Gas Law \& Tax'n 47; H.H. Hillyer, "Problems in Producing and Selling, by Split or Single Stream, Gas Allocable to Diverse Working Interest Ownerships" (1965), 16 Inst. on Oil and Gas Law \& Tax'n 243; C.E. Upchurch, "Split Stream Gas Sales and Gas Storage and Balancing Agreements" (1978), 24 Rocky Mtn. Min. L. Inst. 665. 
602 FAILURE TO TAKE IN KIND - When and so often as a Joint-Operator shall fail or refuse to take in kind and separately dispose of its proportionate share of any production, the Operator shall have the authority, revocable by the Joint-Operator at will (subject to existing sales contracts), to sell for the account and at the expense of that Joint-Operator its proportionate share of production to others at the same price which the Operator receives for its own share of the production or to purchase the same for its own account at the field price prevailing in the area. All sales made by the Operator of a Joint-Operator's share of production as aforesaid shall be for such periods of time only as are consistent with the minimum needs of the industry under the circumstances but in no event shall any contract for the sale of the Joint-Operator's share of production be made for a period in excess of one (1) year. 603 OPERATOR'S FAILURE TO TAKE IN KIND - If the Operator is the party who fails or refuses to take in kind and separately dispose of its proportionate share of production, the Joint-Operators, or any one or more of them, shall have the same rights, mutatis mutandis, with respect to production (including the Operator's share thereof), as the Operator has with respect to a Joint-Operator's share of production under the foregoing provisions of this Article; and in that case the Operator shall follow the instructions with respect to production and marketing given by the Joint-Operators who wish to market and/or take in kind their respective shares of production and to market the Operator's and other Joint-Operator's shares of production as aforesaid. Two or more Joint-Operators exercising their rights under this Clause shall do so in proportion to their participating interests.

604 PAYMENT OF LESSOR'S ROYALTY - Each of the parties hereto shall pay or cause to be paid the Lessor's royalty and all other payments required pursuant to the title documents attributable to its proportionate share of petroleum substances.

605 DISTRIBUTION OF PROCEEDS - Subject to the foregoing provisions of this Article, any party that receives income or proceeds from the sale of another party's share of production, shall forthwith distribute such income or proceeds to the party or parties entitled thereto. If a party fails to distribute such income or proceeds within ten (10) days following its receipt, the undistributed amount may, at the option of the party entitled thereto, bear interest (payable by the party holding such income or proceeds for the account of the party entitled thereto) at the rate provided for in Clause 502, from and after the aforesaid ten (10) days until it is paid.

The 1974 CAPL Operating Procedure is identical to the above, except that it excludes Clause 605, and deletes the following words from line 3 of Clause 601 above: "have the right". The 1971 CAPL Operating Procedure is identical to the 1974 Procedure, but it excludes Clause 604, and refers to Joint-Operators as “Non-Operators".

\section{A. CLAUSE 601}

Clause 601 is quite straightforward. Each party is entitled to its proportionate share of production and has the right to take it in kind and to dispose of it separately. The 1974 and 1971 Operating Procedures, by virtue of the deletion of the words "have the right" in line 3 of Clause 601 above, imply that taking production in kind is an obligation of the parties. However, in light of the presence of Clauses 602 and 603 dealing with failure to take in kind, any breach of this possible "obligation" is unlikely to have any consequences to the defaulting party, other than those contained in Clauses 602 and 603.

\section{B. CLAUSE 602}

Clause 602 is where difficulties in interpretation are encountered. There are a number of phrases which give rise to uncertainty. Several of these phrases which give difficulties to some producers, but in fact should be quite clear will now be examined. 


\section{1. "Shall Have the Authority"}

In the first sentence of Clause 602 , it is stated that whenever a Joint-Operator fails to take in kind, the Operator "shall have the authority" to sell that JointOperator's share. In some situations, Operators have taken the position they will not exercise that authority. Instead the Operator would propose to sell his own share but not to sell the Joint-Operator's; in other words, to leave the Joint-Operator's reserves in the ground. This is not a proper interpretation of the clause. The word "authority" should be read as "obligation" because oil and gas, when produced, is owned by the parties in their proportionate shares. It is not possible to identify one molecule of oil or gas as belonging to one party and not to another. This is one of the basic principles of co-tenancy discussed above. Moreover, Canadian law does not recognize ownership of oil and gas in the ground by a lessee. There is no ownership of oil and gas until it has been produced. Thus, the concept that a Joint-Operator's gas could be left in the ground is absurd. ${ }^{5}$

\section{2. "Revocable ... At Will"}

The converse of this position is also true. The first sentence of Clause 602 goes on to say that the Operator's authority is "revocable by that Joint-Operator at will". In some situations where the Operator is selling a Joint-Operator's production at a price which is unacceptably low to the Joint-Operator, the Joint-Operator has purported to revoke the Operator's authority to market its production. If, however, the Joint-Operator does not have a buyer for the production, it is not possible for that "authority" to be revoked. Whenever production occurs, each Joint-Operator's share is also produced, and it must be sold or otherwise disposed of in some manner.

\section{3. "Subject to Existing Sales Contracts"}

The Joint-Operator's ability to revoke the Operator's marketing authority is stated to be subject to "existing sales contracts". Some uncertainty has been expressed about the meaning of those words. It has been suggested that the Operator's authority to market the Joint-Operator's production is subject to any existing sales contracts that the Joint-Operator has entered into. However, the placement of the words, "subject to existing sales contracts", and the punctuation of the sentence, suggest the proper interpretation is: the Joint-Operator cannot commence taking his share in kind until the contract, to which the Operator has committed the Joint-Operator's production, has terminated. As will be discussed below, the Operator can sell the Joint-Operator's share for such periods of time only as are consistent with the minimum needs of the industry, not to exceed one year.

\section{4. "Field Price Prevailing in the Area"}

The remaining issues which relate to the interpretation of Clause 602 are more difficult. The last portion of the first sentence of Clause 602 provides, that the Operator's sale of the Joint-Operator's production shall be at the same price that the Operator receives for his own share of production, or permits the Operator to purchase 
the same for its own account at the field price prevailing in the area. The clause provides no guidance as to the definition of "the area"; it could mean the pool, the township, the region of the province, or even the province itself. Also, it is difficult to interpret the meaning of the "prevailing" field price. Today there are any number of prevailing prices for gas, depending on the length of the term of the contract, whether it is firm or interruptible, and the nature of the buyer - industrial, commercial or residential. Current field prices for gas vary by more than $100 \%$ between short-term, interruptible industrial sales and long-term system gas sales. Prevailing field price is a concept suited to oil marketing, and is difficult to apply to gas marketing.

Without any case law to guide in the interpretation of this phrase, one can only offer conjecture about its possible meaning. With that in mind, the following points might be considered to be relevant. First, it makes no sense that the definition of the "area" should be interpreted to mean a particular pool, field or township. Gas purchasers from outside the province (who purchase most of the gas produced in Alberta) do not recognize any price differentiations between gas produced in different regions of the province. It is the length of the contract and the nature of the service (firm or interruptible) that are the more important of pricing criteria. Furthermore, the nature of NOVA's "postage stamp" rate structure means the gas to be exported from the province bears the same transportation charge, regardless of whether it was produced in Rainbow Lake or Medicine Hat. This would suggest that the "area" contemplated by Clause 602 could be as broad as the province of production.

The second point that may affect the interpretation of the phrase, "field price prevailing in the area", is the fact that the second sentence of Clause 602 limits the term of any sale of a Joint-Operator's gas to "such periods of time as are consistent with the minimum needs of the industry under the circumstances but in no event in excess of one year." The language of this sentence is another indication that Article VI was not written with the nature of gas marketing in mind. Until fairly recently, the "minimum needs of the industry" in connection with gas sales were 15 years or more. This language makes sense in the context of oil marketing where monthly contracts are common. However, a short-term market for gas has recently emerged, and one year contracts are now fairly common. Even monthly contracts are available through some brokers. When interpreting the "prevailing price" phrase, it would be sensible to take into account the term limitation in the second sentence of Clause 602, so that the "prevailing price" would be the price commonly available for gas under a contract having a term of one year or less. While this interpretation may still leave a wide range of possible market prices, it would at least narrow that range to one in which reasonable persons can come to an agreement, or provide some guidance to an arbitrator.

\section{Sale by Operator at Same Price}

The more important question regarding the latter portion of Clause 602 is whether an Operator must sell the Joint-Operator's share of production under his own contract or a contract with a similar price, or whether he may sell it to another purchaser at a lesser price. This latter event would employ that portion of Clause 602 permitting the Operator to purchase the Joint-Operator's gas for the Operator's account 
at the field price prevailing in the area. It is evident this issue gives rise to considerable uncertainty. The basic principles of the law relating to co-tenancy, and what is understood to be the philosophy underlying the CAPL Operating Procedure, is that the Operator is performing its duties for the joint account, and all of the parties share equally in the benefits and expenses of the operation. This would suggest that the Operator must always sell the Joint-Operator's share at the same price that the Operator receives, which in most cases means that the gas must be sold under the Operator's contract. The question remains what is the meaning of the latter portion of Clause 602 regarding purchases by the Operator for its own account at the prevailing field price? It is suggested this means the Operator may purchase the Joint-Operator's gas for the Operator's own use (and not for re-sale) at the field price prevailing in the area. This would be appropriate where, for example, the Operator is using his gas for a miscible flood project or petrochemical facility and therefore would otherwise attribute a very low price to the gas.

To permit the Operator to buy the gas at the prevailing field price and then re-sell it to others does not give meaning to the words of the preceding portion of the phrase, which provides that the Joint-Operator's share may be sold "to others at the same price which the Operator receives" (emphasis mine). It can be argued that any sale "to others" must be made at the same price which the Operator receives, and not at the prevailing field price.

However, this interpretation is not free from doubt. The language of Clause 602 has the force to override the basic principles of co-tenancy law if it is clear and specific. The circumstances of a particular situation may also affect the outcome of this issue. In this matter, we must await a decision of the courts to aid in the interpretation of this phrase.

\section{Profit by Operator on Re-Sale}

Apart from the issue discussed in the preceding section, an argument can be made that Clause 602 does not permit the Operator to buy the Joint-Operator's gas for the Operator's own account at the prevailing field price and then re-sell it at a profit. In the case Midcon Oil \& Gas Limited v. New British Dominion Oil Company Limited, ${ }^{6}$ an operator and a non-operator each owned $50 \%$ of a gas field. In order to obtain a market for the gas, the operator instigated (with others) the creation of a new company to manufacture fertilizer. As promoter, the operator received a block of shares in the fertilizer company for 1c each and supplied gas to the company. Those shares were shortly worth $\$ 1.50$ each. The non-operator claimed that it was entitled to receive half of those shares for $1 \mathrm{c}$ each. The non-operator lost at trial, on appeal and before the Supreme Court judges who heard the case held that the operator's obligation to account for profits did not go so far as to include profits earned from the shares of the fertilizer company. A majority of the court held the fertilizer company was an enterprise distinct from the ownership and operation of the gas field. The minority found an obligation to account, notwithstanding the remoteness of the profit. If the facts of this case had not favoured the operator as strongly, it would be interesting to know if the court's decision would have been different. 
A number of cases have subsequently considered in the Midcon decision. Some of the principles which have been developed by these cases are:

(a) in the interpretation of a unit agreement, it was held that where words used in the agreement are in their primary meaning, clear and unambiguous, the court should give effect to those words notwithstanding that one party received an unexpected advantage; ${ }^{7}$

(b) where a fiduciary relationship exists, there will be a duty to account for profits when the profiting activity of the fiduciary is sufficiently connected with the scope of its duties. ${ }^{8}$ Unfortunately, none of the cases which discuss this principle involve the sale of production from jointly-owned land; most of the cases on this point relate to the improper use of confidential information. The elements giving rise to a duty to account for profits made from confidential information are secrecy of information, circumstances of confidential disclosure, and unauthorized use to the detriment of the party giving the information. ${ }^{9}$ It is difficult to see how any of these elements would be applicable to the marketing of production. However, this is not to say that these requirements must all be met in order to find a duty to account for profit on the sale of production; ${ }^{10}$

(c) where the interest of the non-operator is restricted to a right to receive a share of the proceeds, fiduciary obligations do not apply. " However, the interest of a Joint-Operator under a CAPL Operating Procedure is more clearly an interest in the land. On the other hand, it could be argued that after production has occurred, the Joint-Operator's interest is restricted to a right to receive proceeds; and

(d) where experienced businessmen have entered into a contract at arm's length with the benefit of legal advice, the courts will not normally find a fiduciary duty to have been created. ${ }^{12}$

The most recent case which considers the fiduciary obligations of Operators, is the decision of the Alberta Court of Appeal in Bank of Nova Scotia v. SocieteGeneral (Canada). ${ }^{13}$ This case, which is commonly referred to as the Sorrel case, involved the question of whether funds held by an Operator in a commingled bank

7. See Canadian Delhi Oil Ltd. v. Alminex Ltd. (1967), 62 W.W.R. 513 (Alta. C.A.).

8. Central Gas Utilities Lid. v. Canadian Western Natural Gas Co. Lid. (1965), 53 W.W.R. 705 (Alta. C.A.); Pre-Cam Exploration and Development Ld. v. McTavish, [1966] S.C.R. 551; Ridgewood Resources Lid. v. Henuset (1982), 18 Alta. L.R. (2d) 68 (Alta. C.A.); Chevron Standard Lid. v. Home Oil Co. Limited, [1982] 3 W.W.R. 427 (Alta. C.A.); Peso Silver Mines Limited (N.P.L.) v. Cropper, [1966] S.C.R. 763; Cully v. Penosky Muller (1977), 2 A.R. 474 (S.C., T.D.); Regehr v. Kirwan (1963), 40 D.L.R. (2d) 338 (Yukon C.A.).

9. Ridgewood Resources Lid. v. Henuset, supra, note 8.

10. Calbar Securities Ld. v. Toole Peet Co. (1984), 30 Alta. L.R. (2d) 286 (Alta. C.A.), supplementary reasons to (1983), 29 Alta. L.R. (2d) 236 (C.A.) (sub nom. Calbar Securities Ltd. v. H \& $B$ Construction Ld.), reversing (1982), 21 Alta. L.R. (2d) 165 (Q.B.); Re Taylor (1982), 13 E.T.R. 168 (B.C.S.C.).

11. Pine Pass Oil \& Gas Lid. v. Pacific Petroleum Lid. (1980), 70 D.L.R. (2d) 196 (B.C.S.C.); Act Oils Lid. v. Pacific Petroleums Lid. , [1972]4 W.W.R. 23 (Alta. S.C.), affirmed (1975), 60 D.L.R. (3d) 658 (C.A.).

12. Francis v. Dingman (1983), 43 O.R. (2d) 641 (C.A.), reversing (1981), 15 B.L.R. 190 (H.C.). Leave to appeal to S.C.C. refused (1984), 23 B.L.R.

13. Bank of Nova Scotia v. Societe-General (Canada) (1988), 58 Alta. L.R. (2d) 193 (C.A.). 
account, and resulting from production from lands governed by a CAPL Operating Procedure, were held in trust for the Joint Operators. After reviewing the provisions of the 1981 CAPL Operating Procedure, the court concluded that fiduciary obligations exist between an Operator and the Joint Operators under the CAPL Operating Procedure.

All of the cited cases are probably distinguishable from the typical re-sale-forprofit situation which arises under a CAPL Operating Procedure. The answer to this issue would appear to tum on whether the purchase of gas from a Joint-Operator, and its subsequent resale by the Operator at a profit, will be "sufficiently connected with the scope of its duties as fiduciary." Also, do the terms of Clause 602 permitting the Operator to buy the gas of a Joint-Operator at the "field price prevailing in the area", end the duty to account for profits? The answers to these questions await the decisions of the court. However, the clear establishment of a fiduciary obligation between an Operator and its Joint-Operators in the Sorrel case strongly suggests that any profit by an Operator in such circumstances is probably not permissible.

The only claim that an Operator is clearly entitled to make, for marketing a JointOperator's gas, is pursuant to the portion of Clause 602 that provides that any sale of the Joint-Operator's production is "at the expense of that Joint-Operator". Even the interpretation of this phrase gives rise to some doubt. Clearly, direct expenses incurred with respect to obtaining the contract under which the Joint-Operator's gas is sold could be charged. The right to claim for indirect expenses is less certain, as would be a claim in respect of pursuing contracts which were not ultimately consummated.

\section{Contracts for Sale by Operator}

Clause 602 permits an Operator to enter into a contract for the sale of a JointOperator's production for a term of up to one year. There is no apparent limitation on this right - it arises whenever a Joint-Operator fails to take his share in kind. Thus, it seems possible that a Joint-Operator, who has a long-term contract but has a nil nomination for one month, could conceivably see his share of gas committed by the Operator to a one-year contract. The Joint-Operator's revocation of the Operator's marketing authority would be subject to the existing sales contract entered into by the Operator. Although actions of this kind make no sense, there is nothing in Clause 602 which would prohibit it. It is suggested, however, that activity of this type by the Operator would be improper if the Operator were aware of the marketing arrangements entered into by the Joint-Operator. Accordingly, a prudent Joint-Operator will keep the Operator apprised of its marketing arrangements, and the length of time that gas sales may be interrupted, if known. Conversely, a prudent Operator will advise his Joint-Operators of the term of the contracts under which their gas is being sold.

\section{CLAUSE 603}

Clause 603 deals with the situation in which the Operator is the party who fails to take its share in kind. In such circumstances, the Joint-Operators, or any one or more of them, shall have the same rights with respect to production as the Operator 
has under Clause 602. Two or more Joint-Operators exercising their rights under this clause are to do so in proportion to their participating interests. It follows that all of the preceding comments, which have been made regarding an Operator's rights and duties under Clause 602, would apply equally to Joint-Operators under Clause 603.

One of the issues that has arisen in practice under this clause is the obligation of an Operator to fulfil the marketing instructions of the Joint-Operator. A basic conflict is involved here between the provisions of Clauses 301 and 603. Clause 301 delegates to the Operator the "control and management of the . . . operation of the joint lands for the joint account ...". Clause 603, on the other hand, provides that where a Joint-Operator is exercising his rights under Clause 603, "the Operator shall follow the instructions with respect to production and marketing given by the Joint-Operators . . .". Which of these two clauses takes precedence? It is submitted that Clause 603 is the more specific, and therefore would override the broad powers of the Operator under Clause 301. This analysis is in accordance with the principle of interpretation that a specific provision takes precedence over a general provision. Thus, the operator would be acting properly in refusing to perform the instructions of the Joint-Operator if those instructions were not in accordance with good oilfield practice. In any other circumstances, however, the Operator ignores the Joint-Operator's directions at his peril. If a Joint-Operator fails to deliver production to its purchaser as a result of an improper refusal to produce by the Operator, and the Joint-Operator suffers damages from that failure, the Operator may well be liable to pay those damages. The Operator's refusal to act may also give rise to an attempt to replace the Operator, pursuant to Clause 202, for defaulting in its duties or obligations.

\section{CLAUSE 604}

Clause 604 is relatively simple, requiring each party to pay or cause to be paid the lessor royalties and all other payments required pursuant to the title documents in proportion to its share of petroleum substances. From time to time some doubts have been expressed about the proper manner for the payment of royalties attributed to split stream sales. Clause 604 does not establish a procedure. It only provides that each party is responsible for paying the lessor royalties attributable to its share. It would seem that producers might want to maintain the usual privity of contract between lessor and lessee, so that the party which normally pays the lessor royalties would continue to do so. This would mean that other producers may have to remit royalty payments to the one producer (typically the Operator) who normally pays the royalties. To the extent that royalties may be considered to be a cost or expense to the joint account, an Operator could employ the provisions of Clause 503 regarding advances of costs and expenses. These issues merit careful consideration by producers involved in split stream sales.

\section{UNIT AGREEMENT ARTICLE VII}

While reviewing Article VI of the CAPL Operating Procedure, it is worthwhile to compare the provisions relating to marketing production from a unit.

Article VII of the 1972 Model Oil and Gas Agreement contains the provisions dealing with the allocation of substances produced from a unit. Clauses 704 and 
705 are the clauses which deal with the matters covered by Article VI of the CAPL Operating Procedure. They read as follows:

704 TAKING UNITIZED SUBSTANCES IN KIND - The Unitized Substances allocated to a Tract shall be delivered in kind at the time and place of production to the Working Interest Owners entitled thereto who may, if there is no interference with unit operations, construct, maintain and operate in the Unit Area all necessary facilities for taking delivery in kind.

705 FAILURE TO TAKE IN KIND - To the extent that a Party entitled to take in kind any of the Unitized Substances fails to take or otherwise dispose of them at the time and place of production, then so long as such failure continues, Unit Operator, as agent and for the account and at the expense of such Party may sell, store, inject or otherwise dispose of them. Where there is a sale the net proceeds remaining from the sale shall be paid to the Party. Unit Operator may contract for the sale thereof only for the minimum term obtainable which in no event shall exceed 1 year. When Unit Operator has so contracted, the Party may take its share of the Unitized Substances in kind upon the expiration of the current sales contract.

\section{A. CLAUSE 704}

Clause 704 is the equivalent of Clause 601 of the CAPL Operating Procedure, but it contains a positive statement that production "shall" be delivered in kind. However, it is difficult to see any liability resulting from a failure to fulfil this apparent obligation in light of Clause 705.

\section{B. CLAUSE 705}

Clause 705 is the equivalent of Clause 602 of the CAPL Operating Procedure and addresses the rights and obligations of a Unit Operator where a party fails to take in kind. It is more descriptive in some respects and less descriptive in other respects than the CAPL Operating Procedure. Accordingly, it is subject to several of the interpretation problems described above regarding Article VI of the CAPL Operating Procedure, as well as certain other problems. No positive obligation is imposed on the Unit Operator to deal with the production share of a non-taking party because it states that the Unit Operator "may sell, store, inject or otherwise dispose" of the share.

\section{Sell}

The Unit Operator's right to sell production would appear not to restrict the Unit Operator to sharing its contract. No reference is made to a sale occurring "at the same price as the Operator receives for its own share of production". Indeed, the only limit on the Unit Operator is to remit the net proceeds of the sale to the non-taking party. The implications of the Midcon case discussed above would apply equally to a Unit Operator, and may affect its rights and obligations under this clause. The use of agency language in Clause 705 makes it clear that a fiduciary relationship is created. The non-operator's revocation rights are set out more clearly than in Clause 602 of the CAPL Operating Procedure.

\section{Store, Inject or Otherwise Dispose}

The Unit Agreement differs from Clause 602 of the CAPL Operating Procedure insofar as it offers the Unit Operator the additional options of storing, injecting 
or otherwise disposing of the production. These options raise some interesting legal issues, particularly relating to the costs of, and entitlement to, injected or stored substances. Who is to bear the costs and risks of injection and recovery? What governs the timing of recovery and the ownership entitlement of injected or stored gas? These options, which are not suitable in all cases, need to be expanded considerably if they are to be exercised without giving rise to considerable dispute.

\section{Unit Operator's Failure}

The Unit Agreement contains no provision similar to Clause 603 of the CAPL Operating Procedure to deal with the rights of other parties if the Unit Operator is the party who fails to take its share in kind. In the absence of specific language, the parties' rights can only be determined under the ancient common law and statutory law principles discussed above.

\section{GENERAL COMMENTS}

There are other comments of general application that should be made about the marketing of production from joint interest properties.

\section{A. BREACH OF DEDICATION}

When more than one buyer purchases gas from different owners of a particular property, it is highly unlikely that the nominations of the buyers will precisely match the participating interests of the producers. Sales by the producers of each other's gas pursuant to Clauses 602 and 603 will be inevitable. However, each producer probably dedicated its reserves to its buyer. Is it not a breach of the dedication to have one producer's gas sold to another producer's buyer? The answer is, yes, this would be a breach of the dedication provision, but a technical breach only. A dedication clause really only works where a buyer contracts for all of the reserves in a pool. In any other circumstances, sale of a portion of a producer's gas to others is practically inevitable. Buyers of gas must be taken to know the nature of standard operating procedures which govern the marketing of gas and should be aware of the consequences to them of failing to contract for all of the reserves. As has been discussed above, the marketing of gas under Clauses 602 and 603 is hardly a voluntary matter. It would seem improper to hold a producer liable for breach of this dedication when the producer's involuntary breach resulted from the buyer's failure to take gas, even if such failure did not constitute a breach of contract by the buyer. Moreover, the calculation of damages in such a situation would be difficult; any loss which the buyer might sustain from the breach is likely to be in the distant future, and possibly remote. Nevertheless, it would be prudent for a producer to include the appropriate provisions in the "Reservations of Seller" article of any gas purchase contracts which the producer may enter into in the future, especially where the buyer is contracting for less than $100 \%$ of the reserves in a pool.

It should be noted that the dedication problem described above may not arise in those gas purchase contracts which acknowledge that overproduction might occur and which require the purchaser to pay overproduction revenues to the parties entitled thereto, or which state that the contract is subject to co-tenants' rights. A 
contract which states that performance is subject to all applicable laws and statutes, may also resolve the dedication problem. A co-tenant's right to take gas and to account for revenue received is a matter of law and statute.

\section{B. WASTE}

Another argument which has been suggested in support of an Operator's right not to produce a well in respect to a Joint-Operator's request (or a Joint-Operator's right to prohibit sale of its production by an Operator) is that the price received for the production is so low as to constitute waste. This argument is probably not effective so long as the production is sold at a market price. Waste is defined as an abuse or destructive use of property which results in substantial injury. Production of oil and gas at market prices, even though those market prices are low, does not necessarily constitute waste. The mere fact that a producer cannot develop new reserves at the price which its current reserves are being sold, or that prices might be higher in the future, is not relevant. However, if the direct costs of production, processing and transportation exceed the sale price of the product on a consistent basis (such that a producer receives an invoice from the Operator which exceeds its revenues), there is at least a potential argument that waste is occurring and the producer who is taking the gas may be liable to its partners.

\section{THE FUTURE}

The foregoing review of the marketing provisions of the CAPL Operating Procedure and an examination of the standard Unit Agreement in light of the current marketing environment demonstrate the need for changes to these marketing provisions. Deregulation and other factors have altered the marketing environment permanently. There is a need to respond to the new marketing environment with revised marketing provisions for jointly owned property.

The current marketing provisions of the CAPL Operating Procedure and the standard Unit Agreement are generally considered to have established an obligation between Operators and Joint-Operators to share their respective production sales contracts where one party fails to take its share of production in kind. Thus, the present joint-marketing arrangement is often referred to as "contract sharing". This method of resolving failures to take in kind suggests that marketing is another of the joint operations undertaken by the co-producers for mutual benefit. However, it has attracted criticism from those producers who do not wish to share the benefits of their marketing efforts, especially with co-producers who do not even attempt to take their share of production in kind.

There appears to be four other methods to deal with a party's failure to take its share of production in kind.

\section{A. CONTRACT SHARING WITH MARKETING FEE}

Co-producers could agree to a "contract sharing" method but provide that the producer who is taking the failing party's production is entitled to a marketing fee. The amount of the fee could be negotiated, and could vary depending upon the type of production (oil, gas, liquids or sulphur) and the price (flat fee or a percentage 
of proceeds). This method suggests that marketing is a joint operation of the co-producers, but gives the marketing producer a benefit for its efforts. It should be noted, however, that the benefit may not reflect the effort undertaken by the marketing producer - it may over-compensate or under-compensate.

\section{B. DISTINCT CONTRACT}

A marketing producer who does not wish to share its contract could be given the right to sell the failing producer's share of production under a separate arm'slength market price contract, and remit the full net proceeds to the failing producer. The marketing producer would not have to share its own marketing efforts, but would not be permitted to profit from the failing producer's share of production. A marketing fee paid to the marketing producer could be incorporated in this method, too. This method implies an underlying philosophy that marketing is not a joint operation under an operating agreement, but a producer may not profit from its co-producer's failure to take.

\section{BUY/SELL}

A third option is to permit the marketing producer to buy the failing producer's share of production at any prevailing market price, and then permit the marketing producer to resell the production and retain any resulting profit. This option suggests that marketing is not a joint operation, and it permits a producer to profit from its co-producer's failure to take. Most large companies with marketing departments prefer this option because they have the marketing personnel and contracts to ensure that their own share of production is taken in kind. Such companies do not wish to share their marketing efforts; in fact they would prefer to profit from a co-producer's failure to take its share in kind. This option permits them to do that.

This option can be somewhat harsh on parties who fail to take in kind. However. some producers respond to this concern by saying that if a party doesn $t$ like the results, it should take its share of production in kind. That is a fair comment, particularly in respect of those producers who make no effort to market their own share of production and rely on their co-producers to do so. On the other hand, failure to take in kind is an event which will occur quite often where there are multiple buyers from a jointly owned property. Moreover, failure to take in kind may occur without the knowledge of the failing producer. By way of example, consider a situation in which an Operator and a Joint-Operator each own an undivided $50 \%$ interest in a certain reservoir. Each of their buyers nominate $2010^{3} \mathrm{~m}^{3}$ of gas per day. The Operator's buyer increases its nomination to $3010^{3} \mathrm{~m}^{3}$ per day. The Joint-Operator is then failing to take in kind. but is not aware of it. The Operator has not told the Joint-Operator of the Operator's higher nomination. nor is the Operator under any obligation to do so. Under this option, the Operator could buy the Joint-Operator's share of the additional nomination (which would be $510^{3} \mathrm{~m}^{3}$ per day) at a current spot price (say $\$ 1.00 / \mathrm{GJ}$ ) and then re-sell it under the Operator's contract or another contract, and keep the difference. 


\section{Draft Article VI of 1990 CAPL Operating Procedure}

The most recent available draft of the next edition of the CAPL Operating Procedure adopts the buy/sell option for dealing with a producer's failure to take in kind. It reads as follows:

\section{ARTICLE VI}

\section{OWNERSHIP AND DISPOSITION OF PRODUCTION}

601 EACH PARTY TO OWN AND TAKE ITS SHARE - Each party shall own its proportionate share of the petroleum substances produced from wells operated for the joint account. The Operator shall measure and deliver into the possession of each party, as and when produced at the first point of measurement, the proportionate share of petroleum substances owned by that party, exclusive of production which has been unavoidably lost and production which may be used by the Operator in producing operations respecting the joint lands. Each party shall, at its own expense, take in kind and separately dispose of its proportionate share of such production. Each Joint-Operator shall provide the Operator with such information respecting such Joint-Operator's arrangements for the disposition of its share of production as the Operator may reasonably require to fulfil its obligations hereunder.

\section{PARTIES NOT TAKING IN KIND -}

(a) Notwithstanding Clause 601 , to the extent that a Joint-Operator fails to take in kind and separately dispose of its share of production hereunder or advises the Operator that it will not be fulfilling that obligation, the Operator shall have the authority, but not the obligation, to dispose of such portion of the non-taking party's share of production, as the agent of the non-taking party, pursuant to any of the following options:

(i) the Operator may sell such production at the same price which the Operator receives from a third party under an arm's length sale contract for its own share of production, and account to the non-taking party for the proceeds of the sale applicable to the production sold on its behalf, less all direct processing and transportation costs pertaining thereto and the applicable marketing fee prescribed by Clause 604; or

(ii) the Operator may sell such production at a market price to a third party in an arm's length transaction, and account to the non-taking party for the proceeds of the sale, less all direct processing and transportation costs pertaining to such production and the applicable marketing fee prescribed by Clause 604; or

(iii) the Operator may purchase such production for the Operator's own account (or the account of an Affiliate) at a market price.

Insofar as the Operator disposes of all or a portion of a non-taking party's share of production pursuant to this Subclause, the Operator shall advise that party in a timely manner of the manner in which the Operator disposed of that party's production.

(b) The Operator may not enter into a sales contract pursuant to paragraph (iii) of the preceding Subclause, unless either such contract has a term not exceeding thirty (30) days or such contract is terminable at any time or not greater than thirty (30) days' notice to the purchaser. If, pursuant to paragraph (i) or (ii) of the preceding Subclause, the Operator proposes to enter into a sales contract which either has a term greater than thirty (30) days or is not terminable at any time on notice of thirty (30) days or less, the following shall apply:

(i) The Operator shall notify the non-taking party of such intention and provide it with a summary of the terms of the proposed contract in sufficient detail to enable the non-taking party to determine whether it wishes that portion of its share of production not being taken in kind and separately disposed of by it sold pursuant to the proposed contract;

(ii) The non-taking party shall notify the Operator within twenty (20) days of the receipt of the Operator's notice whether it consents to having such production sold under such contract, provided that failure of the non-taking party to notify the Operator of its position within such period shall be deemed to be the consent of the non-taking party to the sale of such production pursuant to such contract;

(iii) If the non-taking party consents to having such production sold under such contract pursuant to the preceding paragraph, the Operator shall sell such production under such contract. If 
the non-taking party does not consent to having such production sold pursuant to such contract pursuant to the preceding paragraph, the non-taking party shall state in its notice whether it intends to commence taking such production in kind and separately disposing of the same, and, if so, it shall promptly supply the Operator the information required by it pursuant to Clause 601; or

(iv) If the non-taking party does not consent to having such production sold under such contract pursuant to this Subclause and does not proceed to take such production in kind and separately dispose of the same, the Operator may dispose of such production pursuant to Subclause (a) of this Clause under a sales arrangement having a term either not greater than thirty (30) days or which is terminable at any time on not greater than thirty (30) days' notice to the purchaser.

No contract described in this Subclause, however, shall have a term exceeding one (1) year, unless that contract may be terminated by the Operator at any time on not greater than one (1) year's notice to the applicable purchaser.

(c) If a non-taking party proposes to commence to fulfill its obligation to take in kind and separately dispose of its share of production hereunder, it shall give notice of such intention to the Operator and shall promptly supply the Operator the information required by it pursuant to Clause 601 . Such notice shall be effective either at the end of the term of any sale agreement pursuant to which such production is being sold by the Operator or at the date such agreement is terminated, if terminable by the Operator at an earlier date. However, such notice shall not be effective with respect to an agreement which is terminable by the Operator, unless the Operator has received such notice at least fifteen (15) days prior to any specified date upon which the Operator is required to serve notice to the applicable purchaser to terminate such agreement.

603 OPERATOR NOT TAKING IN KIND - To the extent that the Operator is the party who fails to take in kind and separately dispose of its proportionate share of production, the JointOperators, or any one or more of them, shall have the same rights and obligations, mutatis mutandis, with respect to such share of production as the Operator has with respect to a Joint-Operator's share of production under Clause 602. Insofar as the provisions of this Clause are applicable and the Operator requires instructions respecting production and marketing to give effect to this Clause and, if applicable, Clause 602, the Operator shall follow the instructions which are given by the parties marketing production on behalf of the Operator and, if applicable, any other party hereunder. Two or more Joint-Operators exencising their rights under this Clause shall do so in proportion to their working interests. For so long as the Operator continues to be a non-taking party, it shall advise the other parties periodically when and how it proposes to fulfill its obligation to take in kind and separately dispose of its share of production pursuant to Clause 601.

604 MARKETING FEE - To the extent that a party fails to take in kind and dispose of all or a portion of its share of production and such production is disposed of either by the Operator pursuant to paragraph 602(a)(i) or (ii) or by another Joint-Operator pursuant to Clause 603, other than by way of a transaction described in paragraph 602(a)(iii), the party so marketing such production shall be entitled to charge the non-taking party the marketing fee in ALTERNATE

below (Specify A or B), namely:

ALTERNATE - A:

The party so marketing such production on behalf of a non-taking party may charge that party a marketing fee equal to five percent $(5 \%)$ of the sale price of such production, calculated at the first point of measurement.

- OR -

ALTERNATE - B:

The party so marketing such production on behalf of a non-taking party may charge that party a marketing fee which is a percentage of the sale price of such production, calculated at the first point of measurement, being

(a) in the case of oil, (\%);

(b) in the case of gas, (\%);

(c) in the case of gas liquids and substances other than oil and gas (but not including sulphur), $(\%)$; and

(d) in the case of sulphur, $(\%)$. 
605 PAYMENT OF LESSOR'S ROYALTY - Each party shall pay or cause to be paid the Lessor's royalty and all other payments required pursuant to the title documents which are attributable to its proportionate share of the production of petroleum substances hereunder. However, the party disposing of a non-taking party's share of production pursuant to Clause 602 or 603 may pay the royalty attributable to that share of petroleum substances directly to the Lessor on behalf of the non-taking party, in which case the amount so paid shall be deducted from amounts owing to the non-taking party pursuant to Clause 606.

606 DISTRIBUTION OF PROCEEDS - Subject to the foregoing provisions of this Article, a party that disposes of another party's share of production pursuant to Clause 602 or 603 shall forthwith pay the proceeds of such sale, less all direct processing and transportation costs pertaining to such production and the marketing fee prescribed by Clause 604, to the party on whose behalf such production was sold, and shall include with such payment a statement showing the manner in which the amount was calculated. If the disposing party does not pay such amount within ten (10) days following its receipt, the party entitled thereto may charge the disposing party interest with respect to the amount owing from the day such amount is due until the day it is paid, on the same basis as is provided in paragraph 505(b)(i).

607 AUDIT BY NON-TAKING PARTY - To the extent only that a party sells all or a portion of the share of production of a party which fails to take in kind and separately dispose of the same hereunder, the audit provisions of the Accounting Procedure shall apply, mutatis mutandis, with respect to such sale between the party who sold such production and the party on whose behalf such production was sold, provided that such audit may only be conducted with respect to such sale within the twelve (12) calendar month period next following the calendar month in which such sale was made and that such audit shall be conducted on behalf of the non-taking party by an independent accounting firm which shall be required to keep confidential the proprietary information respecting the sale contract between the selling party and any third party other than an Affiliate of the selling party.

608 NO FIDUCLARY DUTY - The rights and powers given to the Operator pursuant to Clause 602 and to a Joint-Operator pursuant to Clause 603 are in addition to, and are in no way limited by, any express or implied duty, legal or fiduciary, pursuant to this Operating Procedure or otherwise.

The term "market price"' is defined in Article I as follows:

"market price" means a price at which petroleum substances are to be sold (or could be sold) in an arm's length transaction in the market place at the time, which is not unreasonable having regard to market conditions applicable to similar production, including, without restricting the generality of the foregoing, such factors as the volumes available, the kind and quality of petroleum substances to be sold, the effective date of the sale, the term of the sale agreement, the point of sale of the petroleum substances and the type of transportation service available for the delivery of the petroleum substances to be sold.

A review of this Article makes it evident that most of the problems identified with the current Article VI have been dealt with in the new draft. Some of the notable changes are:

(i) In Clause 601, each party is obliged to take its share of production in kind. This is a return to the 1974 CAPL Operating Procedure language. Although Clauses 602 and 603 establish the procedures to deal with a party who has failed to take its share of production in kind, there remains a shadow of possible liability if a party fails to take its share in kind.

(ii) Subclause 602(a) gives the Operator three options to deal with a Joint Operator's share of production which is not taken in kind. Purchase by the Operator at a "Market Price"' is the option which makes this Article a "buy/sell" type provision for dealing with failure to take in kind. The definition of Market Price is very broad, but subclause 602(a) does not state how the Market Price is to be established in a particular situation. Presumably, the Operator will establish the terms for the purchase and will assess 
a Market Price based on those terms. These provisions will be fertile grounds for disputes among co-producers who adopt these provisions.

(iii) If a party wishes to commit another party's share of production to a contract not terminable on 30 days notice or less, the approval of the other party is required as set out in subclause 602(b).

(iv) Clause 604 gives the taking party a marketing fee for selling the failing party's share of production. The fee does not apply where the taking party is purchasing production for its own account. The amount of the fee is a new election provision to be selected by the parties upon adopting into the CAPL Operating Procedure. Alternate A provides for a fee of $5 \%$ of the sale price determined at the wellhead. Alternate B contemplates a negotiated fee applicable to wellhead proceeds determined on a product by product basis. Although the draft appears to contemplate a percentage fee, clearly it would be possible to negotiate a flat fee or volumetric fee if the parties so agreed.

(v) A new Clause 607 contemplates the auditing of a taking party's share of production, by an independent accounting firm that is obliged to keep confidential any contract information.

(vi) Clause 608 is an attempt to override the possible implication of fiduciary duties which may apply to Article VI as a result of the Sorrel case. If the principles of the Sorrel case were to apply to Article VI in the absence of Clause 608, it is possible the option described in paragraph 602(a)(i) would not be effective.

\section{GAS BALANCING}

Gas balancing is probably the most unique option which deals with problems associated with failure to take in kind. It is unique because it moves away from the concept that all production from the reservoir is jointly owned once it is produced, an assumption which underlies all of the other options described above.

Gas balancing agreements are also known as gas banking agreements, underlift/ overlift agreements, storage agreements, out-of-balance production plans, deferred production programs, and by those people who have encountered difficulties with them, a number of other names not suitable for mixed company.

As can be judged by its name, gas balancing agreements are used only in relation to natural gas, where split sales are more problematic. Oil balancing would also be possible, but the nature of the market for oil production has not led to its use.

A gas balancing agreement permits a producer to produce more than his share of production from time to time and to retain the revenue from it. Co-producers who have not produced their respective shares do not receive a portion of the production revenue, but they do earn a gas-in-storage "credit" equal to the amount of the underproduction. An underproduced party may then recover its underproduction by taking more than its share of production in the future.

In the United States, gas balancing agreements have been frequently used, and they have acquired a certain degree of notoriety. Indeed, there is a perception that as a cure, gas balancing is worse than the disease. This should come as no surprise to those who have read a number of gas balancing agreements, most of which are 
dreadfully drafted. In 1986, the Petroleum Joint Venture Association ('PJVA") established a Task Force on Gas Balancing, which prepared an improved guideline form for gas balancing agreements in Canada. A copy of this guideline form, together with the related Guide and Commentary, and Options to the Gas Balancing Agreement is contained in Appendix " $A$ ".

The following are some of the issues which should be dealt with in a gas balancing agreement.

\section{Recovery Rights}

If a producer has underproduced his share, it should have the right to make up its underproduction by taking volumes which would otherwise belong to an overproduced party. The amount of this recovery volume should be established in the gas balancing agreement. In the PJVA guideline agreement, this amount is set at $50 \%$ of the shares of the overproduced parties, although it is a negotiable figure. Seasonal adjustments might also be possible - for example, $10 \%$ in winter, $50 \%$ in summer.

\section{Royalty Obligations}

Royalty obligations are another issue that should be dealt with in a gas balancing agreement. Most gas balancing agreements require the party taking gas to be responsible for royalty payments to lessors, including the lessors of leases owned by producers who may not be taking gas. This arrangement will only work if the royalty rate is identical for all of the lands which are subject to the balancing agreement. This approach is preferred over the approach requiring each party to pay its lessor royalties whether or not it was taking gas. A party not taking gas could face enormous royalty obligations without an off-setting revenue stream.

\section{Operating Costs}

Operating costs pose a similar issue. Should a producer who is not taking gas be obliged to pay a share of operating costs? The PJVA Task Force on Gas Balancing concluded that all parties should pay their pro rata shares of fixed operating costs, and variable costs would be paid by the producers according to the volume of gas taken by them.

Another aspect of production operations that should be kept in mind is that operating costs per unit of production tend to increase over the life of the reservoir. Therefore, the party producing its share later in time would be responsible for the higher operating costs, thereby reducing net revenue.

\section{Limit to Overproduction}

In a gas balancing arrangement, no party should be permitted to produce more than its share of the estimated amount of reserves in the pool. To do otherwise would result in the underproduced party never having the ability to recover its share of production. Indeed, some balancing agreements prohibit a party from taking production once it has taken $75 \%$ or $90 \%$ of its share of remaining reserves. 


\section{Liquidation of Gas Imbalances}

Two key questions are when and how imbalances will be settled if they are not recovered in kind. If imbalances are to be settled periodically - for example, every two years - by a cash payment from the overproduced party, then the total settlement obligation will be limited to the imbalance created over two years. Settlement of imbalances only upon cessation of production is riskier than a periodic system because of the size of the imbalance that could be created, and the risk that a party may be unable to pay or may become insolvent at some time prior to cessation of production.

Once the time for settlement of imbalances is established, the two key issues are the settlement price and security for payment. The settlement price could be the current price paid to the overproduced party or the underproduced party at the time of the settlement, but this is susceptible of manipulation. A more reasonable approach would be to use the price over the preceding year or more or to use a commodity price index of some kind.

Security for payment is a more difficult issue, and is probably a principal reason for the infrequent use of gas balancing. Unless security of some kind is given by an overproduced party, underproduced parties must have faith in the wherewithal of the other producers, as well as trust in the gas balancing agreement, the reservoir and their own marketing abilities, to ensure that imbalances will be recovered by production rather than payment.

Gas balancing is not appropriate for every situation, and is not considered to be appropriate as a replacement for Article VI of the CAPL Operating Procedure. It is too complex an arrangement to be included in a standard operating procedure that is intended to cover all types of reservoirs. However, for those situations where contract sharing, or one of its variations described above, is not acceptable to the producers, gas balancing is a realistic option that deserves more than the swift dismissal it frequently receives.

\section{FACILITIES ISSUES}

The CAPL Operating Procedure generally governs joint operations carried on by co-owners of oil and gas property. However, the issue of exactly which operations are governed arises from time to time. This question is resolved by reviewing the types of costs which are treated as joint costs under the Procedure. The most "downstream" of these costs are the equipping costs. Equipping costs are defined as follows in the 1981 CAPL Operating Procedure:

"equipping costs" means with respect to a well, all moneys expended beyond completion to acquire and install equipment required to produce petroleum substances from the well including, without restricting the generality of the foregoing, the pump (or other artificial lift equipment), the acquisition and installation of flow lines and production tankage serving the well and where necessary a heater, dehydrator or other facility for the initial treatment of the petroleum substances produced from the well to prepare such production for transport to market, but specifically excluding costs incurred beyond the point of entry into a gathering system, plant or other common facility which is or will be operated pursuant to a separate agreement. ("equip" " "equipping", "equipped" and other derivatives of equip, shall have corresponding meanings and relate to those operations in which equipping costs are anticipated or incurred.)

This definition sometimes gives rise to uncertainty in application. It has been suggested that gathering systems and initial treatment facilities which are not 
intended to be governed by a separate agreement will be governed by the CAPL Operating Procedure. This suggestion is based on the specific wording of the exclusionary language which appears at the end of the equipping costs definition. However, it is submitted that this is not a proper interpretation of the exclusionary language. This language refers to "a gathering system, plant or other common facility which is or will be operated pursuant to a separate agreement". The reference to a separate agreement is more properly characterized as a statement (or possibly as a plea) that such common facilities are to be governed by a separate agreement.

Accordingly, the equipping costs definition appears to establish a limit on the application of the CAPL Operating Procedure at a point near the edge of the lease site. There is no clear line of demarcation between facilities which are governed by the Operating Procedure and those which are not. The difficulty which results from this fact is that there are many small-scale, common-ownership facilities which are perceived to be governed by the Operating Procedure, and yet the Operating Procedure does not in fact govern them nor was it drafted in a manner to handle them properly.

The draft of the 1990 version of the CAPL Operating Procedure makes a significant change in this area. A new Clause 1021 is proposed for inclusion in the Independent Operations article. The draft reads as follows:

1021 NON-PARTICIPATION IN PRODUCTION FACILITIES - The parties shall consult with respect to the construction and installation of production facilities and shall attempt to negotiate individual agreements respecting the construction or installation of each production facility or the processing fee to be charged to a party which does not wish to participate in such construction or installation. Notwithstanding any other provision of this Operating Procedure, if the parties are unable to negotiate such an agreement respecting the construction or installation of a particular production facility and the share of the capital costs thereof which is reasonably attributable to the joint lands is estimated to be less than one million dollars ( $\$ 1000000$ ), a party may serve an operation notice respecting such operation pursuant to Clause 1002.

Notwithstanding the provisions of Clause 1002, such notice shall specify in reasonable detail the basis of the allocation of the costs of the production facility between the joint lands and other lands, if applicable, and the fee which a party may elect to pay for the utilization of the production facility if it is not prepared either to participate in the construction or installation of such production facility or to incur a penalty with respect to its election not to participate in such operation. Such fee shall be equitable in the circumstances, having regard to the fee being charged for the utilization of similar facilities in the area of the joint lands and the desire of the parties to provide the parties incurring such costs with a retum of twenty-five percent (25\%) on depreciated capital.

If the production facility is constructed or installed as an independent operation, the following shall apply between the participating parties and the non-participating parties which did not elect to pay the fee prescribed in the operation notice:

(a) If the well(s) on the joint lands to which such operation pertains are held for the joint account, the participating parties shall be entitled to retain possession of the production facility and all production from such wells transported thereby or processed therefrom until the gross proceeds of such production equals the aggregate of:

(i) one hundred percent (100\%) of the Lessor's royalty and any overriding royalties or other encumbrances thereon which otherwise would have been borne by the joint account which are paid with respect to such production, subject to Subclause (c) of this Clause;

(ii) one hundred percent (100\%) of that portion of the cost of operating the production facility which is reasonably attributable to the joint lands, less any fees being paid by a non-participating party with respect to its share of production from the joint lands, as provided in this Clause; and

(iii) two hundred percent (200\%) of that portion of the cost of the construction and installation of the production facility which is reasonably attributable to the joint lands. 
The Operator for the participating parties shall forthwith notify those non-participating parties subject to the penalty upon recovery of the proceeds prescribed by paragraphs (i), (ii) and (iii) above. Each such non-participating party shall have thirty (30) days following receipt of such notice within which to elect to accept or refuse participation in the production facility, provided that failure of such a non-participating party to make an election within such period shall be deemed to be an election to accept such participation in that portion of the production facility reasonably attributable to the joint lands. If such a non-participating party refuses participation as above provided, it thereby shall be deemed to have forfeited its right of participation in and to the production facility, and may thereafter only use such production facility for the transportation or processing of its share of production from the joint lands for such fee as may be negotiated from time to time. If such a non-participating party elects to accept participation in the production facility, its participation in that portion of the production facility reasonably attributable to the joint lands shall be equal to its working interest, and shall be effective as of the time the proceeds prescribed by paragraphs (i), (ii) and (iii) above have been recovered, whereupon the accounts of the participating parties and those non-participating parties so acquiring an interest in the production facility shall be adjusted accordingly. Thereafter, but subject always to the rights of third parties where the production facility serves both the joint lands and other lands, the production facility shall be held for the account of the parties participating therein, and shall be operated by the Operator if it is one of the parties so participating or an Operator appointed pursuant to Clause 1004 if the Operator does not have a working interest in the production facility.

(b) Insofar as Clause 1007 applies to a well to which such operation pertains prior to the recovery of the amounts prescribed by Subclause 1007(a), Subclause (a) of this Clause shall apply immediately following the recovery of the amounts prescribed by Subclause 1007(a), such that a non-participating party with respect to the well may not resume participation in such well until the recovery of the additional amounts prescribed by Subclause (a) of this Clause.

(c) Except to the extent modified in this Clause, Subclauses 1007(b), (c), (d) and (e) shall apply, mutatis mutandis, to this Clause.

This brief clause has major ramifications on the rights and obligations of the parties to the CAPL Operating Procedure. First, it is clear that the Operating Procedure will govern certain facilities that meet the tests set out in the Clause. The total estimated cost of the facilities may not exceed $\$ 1,000,000$. Presumably those facilities which do not meet those requirements are to be governed by separate agreements. It might be appropriate to add other criteria to this list, so that separate facility agreements would be prepared in certain additional circumstances, such as:

(i) where the facility serves more than one property (i.e. serves several properties governed by more than one agreement), because of the difficulties which are bound to arise in dealing with outside substances;

(ii) the facility is processing or handling dangerous substances such as significant proportions of sour gas, which might require special safety and insurance arrangements.

Another significant change resulting from the inclusion of Clause 1021 is the nature of the penalty imposed on a non-participant. In the absence of a provision like Clause 1021, a party which did not participate in a processing, gathering or other similar facility would be permitted to use the facility, but would be charged a fee for its use. In the absence of an agreement on a reasonable fee, resort can be had to the Public Utilities Board to establish the fee. Under Clause 1021, a nonparticipant would bear a much heavier penalty for failure to participate, namely, the complete loss of its revenue from the joint lands up to $100 \%$ of royalty and operating costs, and in addition $200 \%$ of equipping costs would be recovered by the participants out of production revenue. This would be a burdensome penalty, and will particularly concem producers who do not necessarily agree to the type or kind of facility proposed under Clause 1021. For these reasons, it is suggested that it would be more appropriate that Clause 1021 be amended to give each party an 
election regarding an independent notice for a joint facility. The following options would be available: (i) to participate; (ii) not to participate and bear the penalty as contemplated by Clause 1021; or (iii) irrevocably elect to take its share of petroleum substances in kind before the entry point into the joint facility. The third option allows a party who does not support the construction of joint facilities, the ability to produce its share of production without bearing a penalty. This may occur where, for example, the party has access to other facilities for the processing of its production. If the party fails to take its share in kind, a fee would be charged for the use of the facility.

\section{CONCLUSIONS}

Two general conclusions are to be drawn from the discussion above. The first conclusion is that the new circumstances of marketing in Canada have created problems with the application of Article VI of the CAPL Operating Procedure and Article VII of the standard Unit Agreement. Changes are required. The options described above suggest some of the ways in which marketing concerns from jointly owned property can be resolved.

The second conclusion is directed to counsel of oil and gas companies. The philosophy of marketing today is different from that of a few years ago. Gasmarketing and joint venture executives in many companies want to see their companies retain the benefits of their marketing efforts. Where properties are owned jointly with others, this can only be achieved if such plans as gas balancing are adopted, or other significant changes are made to Article VI of the CAPL Operating Procedure and Article VII of the standard Unit Agreement. However, the desire to retain the benefits of a company's marketing efforts are frequently stymied because of the difficulty of entering into new marketing arrangements after the CAPL Operating Procedure or Unit Agreement has been adopted. Counsel for oil and gas companies should ensure that the persons responsible for gas marketing have determined a marketing philosophy for subsequent joint ventures. If the philosophy differs from that reflected in the CAPL Operating Procedure or standard Unit Agreement, suitable changes should be made. The company's landmen should be instructed to ensure that these changes are incorporated into operating, pooling, farmout and participation agreements as well as letter agreements before they are signed. The practice of stapling a CAPL Operating Procedure to an agreement or incorporating it by reference in a letter agreement, without consideration of marketing issues, must stop. This practice fixes the marketing relationship of the parties, probably for all time.

\section{APPENDIX "A"}

\section{PETROLEUM JOINT VENTURE ASSOCIATION GAS BALANCING AGREEMENT GUIDE AND COMMENTARY}

In April, 1986 the Petroleum Joint Venture Association established a Task Force on Gas Marketing from Joint Interest Properties. In the course of its deliberations, the Task Force considered the options available to producers for the marketing of 
gas from joint interest properties if producers did not wish to continue under the provisions of the agreement governing such matters, whether it be a standard operating procedure or a unit agreement. One such option is gas balancing.

Existing gas balancing agreements were found to be inadequate, so the Task Force prepared a new form of agreement as a starting point for producers who wish to implement gas balancing on certain properties. In the course of preparing the new gas-balancing agreement, the Task Force found it necessary to establish a simple fact situation and prepare an agreement to suit that situation. The amendments necessary to deal with more-complex fact situations are outlined in the attached "Options to Basic Agreement" memorandum.

Even though the Task Force prepared the new gas balancing agreement based on a simple fact situation, many aspects of the agreement required the Task Force to make a choice from among a number of options which are available to producers. In selecting the options contained in the gas balancing agreement, the Task Force attempted to be fair and equitable to both overproducers and underproducers. Producers wishing to implement gas balancing may differ in their decisions on these matters depending upon their particular fact situations and preferences. The options which are available to producers when preparing a gas balancing agreement are described in the attached "Options to Basic Agreement" memorandum.

\section{APPLICATION}

The Task Force prepared two forms of gas balancing agreements. One is for use in connection with unitized lands subject to a standard unit agreement, and the other is for use in connection with lands which are governed by a Canadian Association of Petroleum Landmen ('CAPL”) 1971, 1974 or 1981 Operating Procedure. Both forms of the agreement are basically the same, but each incorporates terms and definitions found in the governing operating document. Except where specifically noted, the remainder of this Guide and Commentary will discuss the two forms of the gas balancing agreement as one.

The simple fact situation upon which the agreement was based involves two principles. The first is common ownership of production from the lands governed by the agreement, meaning that the producers have an identical interest in production from each tract among the affected lands. This would clearly be the case for pooled or unitized lands. The second principle is that all of the affected lands are subject to the same lessor royalty rate.

\section{AGREEMENT REVIEW}

\section{Article II - Allocation of Sales Volumes}

Section 2.1 entitles each Working Interest Owner (or Joint Operator, in the case of the CAPL gas balancing agreement) to take its Working Interest Share of production from the affected lands. If a party's nomination is less than its Working Interest Share, the "excess" is allocated among those parties with nominations in excess of their Working Interest Shares. If this excess must be allocated to more than one producer, it is prorated in proportion to the respective Working Interest Shares of such producers. If a party's nomination is greater than its Working Interest Share 
of production, it is entitled to take a volume equal to its Working Interest Share plus its prorated share of any excess available from producers with low nominations.

This approach was thought to be fair and equitable to the producers because it ensures that each may take up to its Working Interest Share. Prorationing the excess on the basis of Working Interest Shares instead of on the basis of nominations was preferred because of the possibility of manipulation. A party could arrange for an unrealistically high nomination and thereby appropriate any excess to itself. Heat content balancing was preferred due to the changing characteristics of gas produced over the life of a reservoir.

Section 2.2 provides that natural gas liquids and plant products other than residue gas are allocated to the parties based on their Working Interest Shares, and are not balanced. This would give some revenue to a party who is not taking gas at a particular time. Only residue gas is balanced under the agreement. Shrinkage gas is also allocated based on Working Interest Shares. This will give each party a basis for making a Gas Cost Allowance claim, notwithstanding that it may not be taking any gas at a particular time.

\section{Article III - Recovery by Underproduced Party}

If an overproduced party is consistently nominating large volumes of gas, an underproduced party may never have an opportunity to make up its underproduction under Section 2.1. Section 3.1 provides that upon notice, an underproduced party may take volumes of gas which would otherwise belong to an overproduced party. The agreement provides that this Recovery Volume may be up to $50 \%$ of the Working Interest Shares of overproduced parties. This is obviously one of the principal negotiating points in the agreement. This percentage could be anywhere from zero to $100 \%$, or could be adjusted seasonally (i.e. $10 \%$ in winter, $50 \%$ in summer). A notice period was thought to be important so that an overproduced party could arrange for alternate supplies of gas for its buyer if necessary. The 30-day notice period provided for in the agreement could be eliminated or extended, depending upon the desires of the parties.

Section 3.2 deals with pro-rata allocations of Recovery Volumes.

Section 3.3 permits a producer to limit the rights of an underproducer under Section 3.1 if the producer is on a deliverability test. Prior notice is required in order to prevent the obvious potential for abuse. This right is limited to three months in each year. Options for this section would include eliminating the notice requirement, and shortening or extending the period for which the right under this section is available.

\section{Article IV-Responsibilities of the Parties}

Section 4.1 discusses the Operator's duties, and limits the Operator's liabilities.

Section 4.2 requires the party taking gas to be responsible for royalty payments to lessors, including the lessors of leases owned by producers who may not be taking gas. This arrangement will only work if the royalty rate is identical for all lands, and that is why common royalty rates are assumed for the simple fact situation adopted by the Task Force. This approach was preferred over the approach requiring 
each party to pay its lessor royalties whether or not it was taking gas. A party that was not taking gas could face enormous royalty obligations without any revenue stream.

Section 4.4 requires parties taking gas to pay production taxes.

Section 4.5 requires the parties to pay fixed operating expenses based on their Working Interest Shares, and Section 4.6 charges variable operating expenses (dehydration, gathering and processing) to the parties based on their shares of Inlet Volumes. If shrinkage is significant, these costs could be onerous for a party not taking gas. Alternatives available here include charging all costs on Working Interest Shares, or on Sales Volumes.

Section 4.3 requires overriding royalties and other burdens to be paid by the party responsible therefor. It was considered by the Task Force that producers should be responsible for their own overrides and other burdens.

\section{Article V-Limit to Overproduction}

Section 5.1 prevents a party from producing gas once such party's cumulative overproduction of gas equals the product of such party's Working Interest Share and Remaining Reserves. This provision may be too generous to overproducers; in order to give greater assurance that production will ultimately balance, taking of gas or overproduction of gas could be limited at an earlier time, for example, $90 \%$ of Remaining Reserves. Alternatively, reaching this limit might also trigger liquidation of imbalances under Article VI.

Section 5.2 sets out the procedure for re-determining the Remaining Reserves. Producers should ensure that the voting procedure is satisfactory. Reserve re-determination could also occur more or less frequently, or could be triggered by an event (i.e. a sudden pressure or deliverability decline).

\section{Article VI - Liquidation of Gas Imbalances}

Section 6.1 deals with the settlement of imbalances after the agreement has been in force for five years, or once production from the lands has ceased. The manner for determining cessation of production is a matter that should be reviewed by producers. The method of liquidation set out in the agreement is based on the Net Price obtained by the overproduced party during the 12 months preceding the date on which such party last took gas. The principle behind this provision is that the overproduced party should have "shared" its contract during the last period during which it took gas. No interest is payable by overproduced parties.

Many other methods are available to determine the liquidation price, including spot gas prices, regulated prices, oil index, etc.

Another option would be to liquidate the imbalance in some means other than cash - for example, the delivery of gas from other lands, or the delivery of any other commodity having value.

Article VI calls for gas imbalances to be liquidated every five years, and at the end of the reservoir life. This could be made more or less frequent if the parties prefer. This would affect potential liabilities of the parties and therefore the risk and size of a potential loss. 
Section 6.2 deals with mechanics of the collection and allocation of funds. One option available here would be to have a third party collect and allocate funds.

Risk of loss could be dealt with by providing overproduced parties to put up some form of security for their potential liabilities.

\section{Article VIII - Miscellaneous}

Section 8.2 deals with assignment. Some of the options available here would be to require the assignor to remain liable for obligations under the agreement notwithstanding assignment. Another option would be to require any overproduced party who wished to assign its interest to liquidate its share of the imbalance as a pre-condition to the assignment. Restraint on assignment is an important part of the agreement, and should be considered by producers.

\section{TERMS INCORPORATED BY REFERENCE}

Both the Unit Agreement and CAPL forms of gas-balancing agreement incorporate by reference various terms defined in the Unit Agreement and the CAPL Operating Procedure, respectively. The definitions which are used in the gas balancing agreements are:

Unit Agreement
Royalty Owner
Unit Operator
Unit Operating Agreement
Unitized Zone
Working Interest Owner

1974, 1981 CAPL

Operating Procedure

joint lands

Joint-Operator

operating costs

Operator

participating interest party

\section{PETROLEUM JOINT VENTURE ASSOCIATION GAS BALANCING AGREEMENT OPTIONS TO BASIC AGREEMENT}

The following is a discussion of some of the options that can be used in a gas balancing arrangement. The following discussion of options are referenced to the Articles of the gas balancing agreement prepared by the Task Force.

\section{Article I-Definitions}

(a) Definitions - Definitions to be used in the gas balancing agreement should be the same as those used in the Unit Agreement or CAPL Operating Procedure. Key differences could be in the use of the term Gas, Sales Volume, or Working Interest Share. An option would be to include all of the definitions in the Unit Agreement or CAPL Operating Procedure in this article.

(b) Net Price - The Net Price could have a ceiling such that this price is not greater than the actual price received by the overproducer when the gas was sold. A floor price or ceiling price could also be established. It may be appropriate to 
use an external pricing source of gas. This could be the TCPL, NUL, or A\&S field prices, the average price for gas sold from that field, the current industrial spot price in Alberta, an oil price index, or any other methods that the parties can agree on, instead of the Net Price as defined.

The Net Price definition also explicitly covers the situation where an Overproduced Party took Gas for its own use. In this case, the price used in the Net Price calculation would be the fair market value of $\mathrm{Gas}$ at the time of liquidation.

\section{Article II - Allocation of Sales Volumes}

(a) Balance on the basis of volume - Balancing on the basis of volume has the advantages of being simple and easier to administer. There does entail some risk to the parties if the reservoir conditions change significantly over the term of the gas balancing arrangement, or if plant efficiency changes.

(b) Balance on inlet volume - This moves the point of balancing from the tail end to the front end of the plant. This may be useful in a specific instance where gas from a field is being processed at different gas plants. Balancing on inlet gas could be done on a heat-content basis, but due to the expected difficulties of getting accurate compositions, may best be done on a volume basis.

(c) Allocate excess on nominations - Allocating excess on nominations leaves an opportunity for manipulation of the sales volume. A party could ask its buyer to set an unrealistically high nomination so that the party can sell the majority of the gas from the Unit in that month. If done in good faith, allocating excess on nomination would result in the party who has been most successful in obtaining markets, being better able to satisfy those markets.

(d) Plant Products allocation based on sales volume - Allocating Plant Products such as natural gas liquids, sulphur or other products based on sales volume could have the result of certain owners not receiving any revenue in any specific month. In fact, they could be owing money to the other parties to help pay for fuel and other fixed operating costs.

\section{Article III - Recovery by Underproduced Party}

(a) Notice period - It is incumbent upon an underproduced party, who wishes to recover some underproduction, to notify the remaining parties. Otherwise, an overproducing party could suddenly find himself without sufficient gas to satisfy the contracts it has brought to the field. The existing agreement has provided for a 30-day notice period. A longer notice period would give overproducing parties ability to market their gas under more assured conditions, and thereby possibly receive a higher price for the gas. For example, if a marketer of gas knew that his gas supply was secure for one year instead of one month, that could increase the price and the number of potential purchasers of that gas. On the other hand, in a deregulated and evolving gas market, opportunities to sell gas may only be available on a very short-term notice. An underproduced party may wish to be able to take advantage of these short notice periods by reducing the notice period to three to four days.

(b) Seasonal restriction on recovery - An option discussed is that an underproduced party could not recover all of his gas in the winter time. This would be 
fair to the overproduced party, who has been able to market gas on a year-round basis and is relying on winter supply to satisfy its customer. A suggestion is that an underproduced party be allowed to recover no more than $50 \%$ of that year's overproduction during the winter heating season.

(c) Recovery percentage - An underproduced party has a right to recover his underproduction, but as in item 3.2, this should not cause severe hardship to the overproduced parties. Setting a low recovery percentage could result in the underproduced party not recovering the underproduction until late in the reservoir life. Setting it at $100 \%$ could significantly disadvantage the overproduced parties by withdrawing their gas supply at critical moments in the heating season. This is open to negotiation.

(d) Allocating recovery volumes - The agreement provides for allocation of recovery volume to be based on the ratio of the cumulative underproduction of underproduced parties. An alternative could be on working interest share. The rationale behind this is that a working interest share is a measure of the amount of capital that a party has put into producing the field, and is thereby due to it in attempting to recover underproduced volumes.

(e) Deliverability test - The provision of a right to prohibit recovery by an underproducer during an overproducer's deliverability test could be subject to manipulation. This could preclude an underproduced party from recovering gas from an overproduced party if that overproduced party is continually on test. Due to the differences in deliverability provisions under different gas contracts, no one clause will completely satisfy both overproduced and underproduced parties.

Many contracts have a testing period of fifteen (15) days in a month. An alternative would be that fifteen (15) days would be the maximum amount of time a party could be on test. An alternate is to have each party specify in its individual gaspurchase contract that deliverability tests shall require notice to the producer. This notice period could then allow a producer to notify other associates when a deliverability test could be expected.

\section{Article IV - Responsibilities of Parties}

(a) Paying lessor royalties - An option is to have each party pay lessor royalties regardless of whether or not it is taking gas. This is an incentive for an underproduced party to market gas.

The mechanism for the payment of royalty by overproducers to the underproducers' royalty owners can be done a number of ways. The conflicting factors are the need to maintain price confidentiality and the desire to minimize the number of signatories to a gas balancing agreement. The three options outlined below partially satisfy these criteria.

(i) The overproducer will pay royalty to the underproducer's royalty owner via the underproducer based on a deemed price with a 13th month adjustment.

(ii) The underproducer's royalty owner agrees to defer royalty until gas is actually sold by the underproducer.

(iii) The overproducer enters into a separate agreement with all of the underproducers' royalty owners for the direct payment of royalties. Note that 
if there is only one royalty owner, i.e. the Crown, then separate agreements between overproducers and the Crown would likely not be required.

(b) Overriding royalty payments - An option is to have the overriding royalties paid by the overproduced party. This would lighten the burden on the underproduced party, but could significantly decrease the incentive to market gas. As most overriding royalties are not public, it will also involve disclosure of confidential contractual arrangements between third parties and a party. This could be circumvented by having the overriding royalty holders participate in the gas balancing agreement and agree to determine overriding royalties on the basis of the gas sold by the party responsible for the overriding royalty.

(c) Third party royalty payments - To avoid the sharing of price information, signers to this Agreement could use a third party to handle the calculation of payments of royalty for overproduction. A reputable chartered accountants firm could be engaged to receive the over and underproduction volumes, the price information from the overproducer, the royalty percents payable and any other information required. The third party would then calculate the amount of royalty due the royalty owner and remit the amount to the royalty owner as an agent of the underproduced party.

(d) Field costs - Field costs could be based on sales volumes. This would lighten the burden on the underproduced party when the underproduced party is not taking any gas. On the other hand, many of those costs would be payable whether or not gas is being sold, and as a working interest owner, the underproduced party has an obligation to pay those costs. Another option is that all costs be allocated on a working interest basis, regardless of volume produced.

(e) Use of interim prices - To avoid the perception of sharing of price information, an interim price for the year could be used as a basis for calculating royalties payable by overproducers. For example, the price of gas sold by an overproducer could be assumed to be $60 \%$ of the Western Gas Marketing Ltd. (WGML) field price. That would be in operation for one calendar year and a thirteenth month adjustment could be made in January of the following year. This eliminates, or decreases, the value of the information that could be transferred among the associates. The danger in this is that the overproducer wishes the interim price to be as low as possible to avoid paying out money that may be difficult to recapture later, and the underproducer wishes a high price to avoid having to extract funds from the overproducer in a thirteenth month adjustment.

(f) Varying costs - A concern was expressed that the monthly operating costs could vary significantly. An operator could, by design or default, show significantly different unit operating costs in one month versus the next. In the same manner, large expenses could be incurred in one year (i.e. a new charge of sweetening solution or a major tower repair) that would be onerous on an overproducer, who would be paying the lion's share of operating costs for that time period. A way out would be to equalize operating costs over the year or, if considered warranted, to equalize operating costs over the full five-year term of this Agreement.

(g) Taking gas in kind - The question was raised of how to value gas if it is taken for internal use. Right now, there is no royalty payable on that gas if it is used elsewhere in a miscible flood or EOR project. Overproducing by one party for its own use should not pose a problem until it comes time for liquidation of damages. 
At this point, the calculation of net price and fair market value concept would determine the value of the gas.

(h) Increased Overhead Costs - An operator could ask for an increase in the overhead payment because of the extra effort required to account for the allocation of sales volumes, liquids production, royalty calculation, cheque distribution, etc. This increase should be considered on a case-by-case basis. It is expected that most allocation systems are computerized to some degree and that on-going costs of gas balancing would be small once the system has been set up. Also, some of the gas balancing accounting would be done at the field so costs are charged back directly to the joint account.

\section{Article V-Limit to Overproduction}

(a) Limit of working interest share of reserves - The agreement prevents a party from producing gas once such party's cumulative overproduction of gas equals the product of such party's working interest share and remaining reserves. In an area where reserves determination is a contentious issue, this may cause some concerns to potentially underproduced parties. Restricting overproduction to, say, 50 or $75 \%$ of a party's working interest share may be appropriate. However, for new fields where a significant amount of appreciation or reserve enhancement can be expected, it may be appropriate to remove the limit on the amount of overproduction. Then the underproduced parties would have to rely on either reserve appreciation or a liquidation of damages upon field depletion.

Another option is to put no restriction on the amount of overproduction that any working interest owner can sell.

(b) Reserves determination - The operator has a responsibility for determining reserves. This could be farmed out to an independent third party. These reserve determinations could also be taken as final once the third party provides its report.

(c) Frequency of reserve determination - The agreement provides for reserve determination no more than once per year. In an older field, this may be much too frequent. An alternative would be each time $10 \%$ of the remaining reserves have been produced.

\section{Article VI - Liquidation of Gas Imbalances}

(a) Cessation of production - The exact time when a unit ceases production can be open to interpretation. For example, if a unit is shut down for six months, does that qualify as cessation? Conversely, if the unit is designed for 80 million a day and is still producing one million a day, does that qualify as still being on production? In a unit, there is a procedure whereby the Operating Committee has jurisdiction in determining cessation. An alternate could be that liquidation of imbalances occur when the remaining reserves are equal to less than $5 \%$ of the original gas in place.

(b) Payment of imbalance - Overproducers could compensate underproducers in any commodity of value, be it dollars, gas, liquids, oil, shares in the company, etc. For example, if liquidating using gas, the balancing agreement could specify that for repayment certain quantities of gas should be delivered to Inland station on behalf of underproduced parties. The imbalance could also be settled by allowing 
the agreement to continue in place beyond five years but preclude any overproduced party from further overproduction. During this time, an underproduced party would retain its rights to recover gas from the overproduced parties.

(c) Allocation of funds - The agreement has the operator allocating funds. It may be more appropriate to have an outside third party, for example a chartered accountancy firm or a lawyer, to be entrusted with the receipt and dispersal of funds.

(d) Royalty status changes - Liquidation must not change the status of the gas that has already been produced. Specifically, gas that has already moved to an internal market cannot retroactively be deemed to have been sold. A liquidation settlement should be made using GJ of gas rather than money.

(e) Liquidation pool - If the pool is still producing near the end of the five-year term, the parties could liquidate any imbalance by having the overproducer shut-in some production in the fifth and final year of the Agreement. This would eliminate any need for payment of dollars from overproducer to underproducer. As our Agreement currently stands, it assumes there is no gas available to balance accounts.

(f) Security for underproducer - The concern was raised that an overproducer may be not financially solvent upon initiation of overproduction. One way to resolve concerns is for the overproducer to have some sort of letter of credit, or to allow the creation of a lien against other gas reserves.

\section{Article VII - Term}

The current agreement calls for gas imbalances to be liquidated on a five (5) year term. This may cause some concern to parties who are unsure of their marketing capabilities. To have this term for anything less than one to two years would make it of minimal value. Gas balancing on a less than one year basis is quite commonly done right now. However, a fixed-term agreement with evergreening upon approval is feasible. If the parties prefer, the term of the agreement could continue for the full life of the pool.

\section{Article VIII - Miscellaneous}

(a) Assignment provisions - Assignment could be a cause to trigger a liquidation of imbalances. Also, the restriction on assignment could be removed if the assignor is in balance and the assignee agrees in writing to be bound by the agreement.

It was recognized that the constraint on assignment is meant principally for overproducers. Section 8.2 could be changed to apply the constraint only to overproducers. However, all parties entered into the gas balancing agreement with knowledge of the potential overproducers and underproducers and their creditworthiness. Had those parties been different, the gas balancing agreement may not have been signed. The concern is that an overproducer may assign its interest to a party that is significantly less credit-worthy.

(b) Additional costs - Participants could be required to recognize and share in the additional set up and on going costs of accounting and allocating over and under production. 
(c) Insolvency - The agreement does not address the situation where one of the party becomes insolvent or bankrupt. Both parties could create contingent liabilities for each other, hence, agreement must be in place to provide safeguards to each party. This could include obtaining guarantees, such as letters of credit, from third parties to secure the excess gas sold by the overproducer. Control procedures should include those which would provide warnings of financial instability.

(d) Business practices - A section could be added to ensure that sound business practices and financial reporting are being adhered to.

(e) Audit - A clause could be added to provide audit access to verify compliance with the agreements.

(f) Unit Enlargement - Unit enlargement would be permitted, and should not affect the rights and obligations of existing working interest owners as long as the new owner signs the agreement.

\section{APPLICATION TO ALTERNATIVE FACT SITUATIONS}

\section{Non-Common Ownership of Lands}

In this fact situation, the gas balancing agreement must be amended to establish a separate balancing account for each well or tract of land in which there is common ownership percentages. A similar approach would be used if there is production from multiple zones - each zone would be balanced separately. This could significantly complicate accounting under the agreement.

\section{Non-Common Royalty Rates}

Again, the most likely approach for dealing with this complication is to balance each well or lease or tract of land in which there is a common royalty rate. Another option would be to have the royalty owners consent to and participate in the balancing scheme. Alternatively, a "lowest common denominator" royalty could be determined and paid by the party taking gas, with the party responsible for the royalty being obliged to pay the balance, whether or not it was taking gas. Another option is to require each party to pay its royalties regardless of whether it was taking gas.

\section{Less Than $100 \%$ Participation}

If less than $100 \%$ of the working interest owners wish to participate in the gas balancing agreement, then one or more of the parties expecting to overproduce can enter into a purchase arrangement with the non-participants which would come into effect when the non-participants fail to take their share in kind.

\section{PETROLEUM JOINT VENTURE ASSOCIATION GAS BALANCING AGREEMENT}

Note: This draft Gas Balancing Agreement has been prepared for unitized lands which are subject to a standard Unit Agreement, and is appropriate for situations in which all lands in the Unit are subject to a common royalty rate. 


\section{GUIDELINE AGREEMENT (UNIT)}

19

THIS AGREEMENT made effective the day of

BETWEEN (AMONG):

[DESCRIBE PARTY] (herein called “

OF THE FIRST PART

- and -

[DESCRIBE PARTY] (herein called “

OF THE SECOND PART

- and -

[ADD ADDITIONAL PARTIES AS NECESSARY]

WHEREAS and are Working Interest Owners in the Unit;

AND WHEREAS each Working Interest Owner has made (or will make) arrangements to sell or utilize the share of the Gas produced from the Unitized Zone attributable to such Working Interest Owner's participating interest;

AND WHEREAS it appears that such arrangements of the Working Interest Owners may allow commencing delivery at different times or be limited from time to time;

AND WHEREAS the Working Interest Owners desire the flexibility to permit the taking of Gas from the Unitized Zone on a disproportionate basis from time to time;

NOW THEREFORE THIS AGREEMENT WITNESSES THAT the Working Interest Owners have agreed as follows:

\section{ARTICLE I}

\section{DEFINITIONS}

1.1 In this Agreement, except as specifically provided for herein, terms defined in the Unit Agreement or the Unit Operating Agreement shall have the same meaning herein.

1.2 In this Agreement:

(a) "Affiliate" means, with respect to the relationship between corporations, that one of them is controlled by the other or both of them are controlled by the 
same person, corporation or body politic; and for this purpose, a corporation shall be deemed controlled by those persons, corporations or bodies politic who own or effectively control sufficient voting shares of the corporation (whether directly through the ownership of shares of the corporation or indirectly through the ownership of shares of another corporation which owns shares of the corporation) to elect the majority of the board of directors;

(b) "Gas" means that portion of Raw Gas production from the Unit, delivered at the outlet of the Plant, that remains after being processed at the Plant and which is composed essentially of methane, but excludes such portion as is lost in processing or consumed as fuel;

(c) "Inlet Volume" in any month means the volume of Raw Gas allocated to a Working Interest Owner as its share of Raw Gas entering the Plant during that month as determined in accordance with this Agreement;

(d) "Net Price" means the price received for Gas sold on an arms-length basis at the outlet of the Plant by an Overproduced Party on a volume weighted average basis for the 12 month period in which such party took Gas preceding the last month of sales by such party, or the fair market value at the time of liquidation under Section 6.1 of Gas taken by an Overproduced Party for such party's own use or sale to an Affiliate, less:

(i) lessor royalties paid during such period;

(ii) operating costs, other than those costs of the type described in Section 4.5, charged to such party in accordance with the terms hereof and the terms of the Unit Operating Agreement during such period; and

(iii) production and royalty taxes paid during period in respect of such production;

(e) "Overproduced Party" means a party who has sold more than its Working Interest Share of Gas produced from the Unit;

(f) "party" means a person, corporation or body politic bound by this Agreement;

(g) "Plant" means the gas processing facility where production from the Unit is processed, located at

(h) "Raw Gas" means natural gas (which may include hydrocarbon liquids, water and other constituents) produced from the Unit and which has not been processed at the Plant;

(i) "Recovery Volume" has the meaning set out in Section 3.1;

(j) "Remaining Reserves" means the total remaining recoverable Gas reserves from the Unitized Zone as established or redetermined from time to time in accordance with Section 5.2;

(k) "Sales Volume" in any month means the volume of Gas which a Working Interest Owner's Gas purchaser has requested and purchased for that month;

(l) "Shrinkage Volume" in any month means the volume of Raw Gas allocated to a Working Interest Owner as its Working Interest Share of shrinkage gas resulting from the operation of the Plant during that month;

(m) "Underproduced Party" means a party who has sold less than its Working Interest Share of Gas produced from the Unit; 
(n) "Unit" means the

(o) "Unit Agreement" means the Unit Agreement for the Unit; Unit;

(p) "Unit Operating Agreement" means the Unit Operating Agreement for the Unit; and

(q) "Working Interest Share" means the participating interest of a Working Interest Owner in the Unitized Zone.

\section{ARTICLE II}

\section{ALLOCATION OF SALES VOLUMES}

2.1 Each Working Interest Owner shall be entitled to take its Working Interest Share of total production of Raw Gas from the Unit or up to its entitlement as described in Section 3.1 herein. If the Sales Volume of a party is less than its Working Interest Share, the excess volumes shall be allocated to those parties with Sales Volumes in excess of their Working Interest Share of total production pro rata in proportion to the respective Working Interest Shares of such parties. Any imbalances between a party's Working Interest Share and actual allocated sales shall be recorded by the Operator, converted to heat content values, and a statement of cumulative over and under production, on a heat content basis, shall be furnished with the monthly allocation statements.

2.2 All natural gas liquids and Plant products other than Gas which are sold or otherwise disposed of shall be allocated to the parties based on their respective Working Interest Shares. All Shrinkage Volumes shall be allocated based on each party's Working Interest Share. Each party's Inlet Volume shall be equal to the sum of its Sales Volume and Shrinkage Volume.

\section{ARTICLE III}

\section{RECOVERY BY UNDERPRODUCED PARTY}

3.1 In addition to any recovery of underproduction that may occur under Section 2.1 , an Underproduced Party must give at least 30 days notice to all Working Interest Owners of its intention to commence recovery of underproduction by taking volumes in excess of its Working Interest Share. After giving such notice and if not precluded by any other terms of this Agreement, an Underproduced Party shall be entitled to take, in addition to its Working Interest Share, a volume of Gas (the "Recovery Volume"') up to $50 \%$ of the total Working Interest Shares of Overproduced Parties.

3.2 If two or more Underproduced Parties, pursuant to Section 3.1 above, are recovering underproduction at the same time, allocation of Recovery Volumes shall be based on the ratios of the cumulative underproductions of the Underproduced Parties. The Recovery Volumes taken from the Working Interest Shares of Overproduced Parties shall be apportioned based on the ratios of the cumulative overproductions of Overproduced Parties. 
3.3 Each Working Interest Owner shall have the right to deliver to its Gas purchaser its full Working Interest Share of the maximum or allowable Gas production to meet a deliverability test by such purchaser, provided that such party shall first provide notice to the Operator and all other parties of its requirement for the Gas. A party cannot exercise its rights under this Section 3.3 for a cumulative period in excess of two months in each year.

\section{ARTICLE IV}

\section{RESPONSIBILITIES OF PARTIES}

4.1 The Operator shall have the duty of controlling Gas production and the responsibility for administering the provisions of this Agreement. The reasonable and good faith determinations of Operator in performing its duties and responsibilities shall be binding on the parties and the Operator, in its capacity as Operator, shall not incur any liability to any party except for loss or damage resulting from its gross negligence or wilful misconduct or that of its agents and employees.

\subsection{For purposes of determining obligations to pay lessor royalties, each party} taking more than its Working Interest Share of Gas for any month shall be deemed to have taken a portion of the Gas not taken by each party taking less than its Working Interest Share equal to such overtaking party's share of the total overproduction for the month. Other provisions contained in the Unit Operating Agreement notwithstanding, each party taking more than its Working Interest Share of Gas shall be responsible for the payment of lessor royalties thereon. Each overtaking party shall pay to the undertaking parties the share of such lessor royalties which the undertaking parties would otherwise be obliged to pay had this Agreement not been entered into. Such payment shall be made at least three days prior to the royalty payment date established by the Leases in question. Each party taking less than its Working Interest Share at any time hereby indemnifies the other parties hereto against the claims, demands and causes of action which have as their basis an alleged entitlement to payment in excess of that received from the party taking the Gas, or which may be brought by Royalty Owners to whom such indemnitor is obligated under the Leases.

4.3 All royalties (except lessor royalties), overriding royalties and other burdens applicable to each party's Working Interest Share in Gas production shall be paid by the parties responsible therefor [in accordance with the Unit Operating Agreement]. Each party indemnifies all other parties hereto against any claim by, or liability to, any owner of royalties (except lessor royalties) or other interests in Gas production burdening its Working Interest Share regardless of such party's capability to utilize or sell its Working Interest Share of Gas. The parties shall provide to each other such information as may be required in order to determine payments required to holders of royalties (except lessor royalties) and other burdens.

\subsection{Each party taking Gas shall pay any and all production taxes due on such Gas.}

4.5 Field expenses, which shall include but are not limited to surface rentals, lease maintenance, access roads, workovers, and other costs that do not vary with the 
volume of production, and which shall exclude costs of the type described in Section 4.6, shall be charged to parties based on their respective Working Interest Shares.

4.6 Costs attributed to dehydration, gathering and processing, and other costs that vary with the volume of production, shall be charged based on Inlet Volumes as determined pursuant to Section 2.2.

\section{ARTICLE V}

\section{LIMIT TO OVERPRODUCTION}

5.1 Notwithstanding Section 3.3, no party shall take Gas after such party's cumulative overproduction of Gas taken equals the product of $75 \%$ of such party's Working Interest Share and the Remaining Reserves.

5.2 The parties agree that the Remaining Reserves as at

$19 \_$are $10^{3} \mathrm{~m}^{3}$. Any party can request that the Operator redetermine the Remaining Reserves provided that the Operator shall not be required to redetermine the Remaining Reserves more than once per year. The Operator shall submit for approval its redetermination of the Remaining Reserves to the other parties via a mail ballot in accordance with the Unit Operating Agreement. If the Operator does not receive approval for the redetermination of the Remaining Reserves, the Operating Committee shall commission an independent third party chosen by the Operator to redetermine the Remaining Reserves. The independent third party's evaluation shall be binding on all parties. The cost of the third party's evaluation is to be charged to the Unit operating expense account and borne by all parties in proportion to their Working Interest Shares.

5.3 If an Overproduced Party has ceased production because such party's cumulative overproduction of Gas taken equals the product of such party's Working Interest Share and the Remaining Reserves, the Overproduced Party may resume production if the most recent reserve determination shows greater reserves than the previous reserve determination.

\section{ARTICLE VI \\ LIQUIDATION OF GAS IMBALANCES}

6.1 If at the end of the fifth year of this Agreement, or when production from the Unitized Zone has permanently ceased as determined by the Operating Committee (whichever first occurs), and there exists at that time a production imbalance, the settlement due to the Underproduced Parties shall be determined and settled in the following manner:

(a) each Overproduced Party shall contribute to a liquidation pool established by the Operator a sum of money equal to the product of such party's volume of overproduction and such party's Net Price; and 
(b) the Operator shall distribute the liquidation pool proceeds to the Underproduced Parties in accordance with the ratio of their respective underproduction.

6.2 The Operator shall be responsible for the determination of over and under production and the amounts to be contributed to or withdrawn from the liquidation pool by each party. The Operator shall receive and promptly distribute the liquidation pool funds, and such funds shall be kept in a segregated trust account. The Operator shall prepare invoices for the Overproduced Parties within 60 days after the Operating Committee has determined that production from the Unitized Zone has permanently ceased. Parties required to contribute to the liquidation pool shall do so within 30 days of receiving an invoice from the Operator for their contribution. The Overproduced Parties shall provide such information as may be reasonably required by the Operator in order to permit the Operator to calculate the Net Price.

6.3 The Operator shall not be liable to Underproduced Parties in its capacity as Operator for any deficiency in the liquidation pool if an Overproduced Party does not contribute its required moneys to the liquidation pool.

6.4 For the purpose of calculating the Net Price of an Overproduced Party, an Underproduced Party may dispute the gross price for Gas sold or used by the Overproduced Party if the Gas sold by such party during the relevant 12 month period was sold to an Affiliate of the Overproduced Party or utilized by the Overproduced Party without a sale thereof. If the parties cannot agree on a fair market value price for such Gas, then the determination of such fair market value price shall be referred to an arbitrator pursuant to the Arbitration Act. The costs of such arbitration shall be borne by the Underproduced Party or Parties which disputed the gross price used by the Overproduced Parties.

6.5 If the title of a party to the Unitized Zone should fail or be surrendered, then:

(a) if that party is an Overproduced Party, it shall immediately settle its overproduction balance in the manner set out in Section 6.1 above, mutatis mutandis; or

(b) if that party is an Underproduced Party, then it shall no longer have any right to recover its underproduction balance until settlement occurs in accordance with Section 6.1 above.

\section{ARTICLE VII}

\section{TERM}

7.1 This Agreement shall be effective as of the date first above written, and unless extended in writing by the parties, shall terminate upon the earlier of the end of the fifth year of this Agreement or the permanent cessation of production from the Unitized Zone as determined by the Operating Committee; provided that the obligations of the parties under Article VI shall continue after termination. 


\section{ARTICLE VIII}

\section{MISCELLANEOUS}

8.1 This Agreement is binding upon the Working Interest Owners and their respective successors and permitted assigns.

8.2 No party may assign its interest in the Unit or in this Agreement without the prior written consent of the other parties hereto.

8.3 Each party hereby indemnifies and agrees to defend the other parties against all liability for claims which may be asserted by third parties under any contract, whether now or hereafter existing, between said third party and such indemnifying party and arising out of the operation of this Agreement or activities of any party under its provisions, and further agrees to save the other parties harmless from all judgements or damages sustained and costs incurred in connection therewith.

8.4 This Agreement supersedes the provisions of Clauses 704, 705 and 1201 of the Unit Agreement and Clause 1201 of the Unit Operating Agreement insofar as such provisions affect the rights and obligations among the Working Interest Owners.

8.5 Article headings and any other headings or captions or index hereto shall not be used in any way in construing or interpreting any provision hereof.

8.6 Unless otherwise expressly stated, whenever the singular or masculine or neuter is used in this Agreement, the same shall be construed as meaning plural or feminine or body politic or corporate or vice versa, as the context so requires.

8.7 No amendment or variation of this Agreement shall be binding upon any party unless it is evidenced in writing, executed by all the parties.

8.8 This Agreement shall for all purposes be construed and interpreted according to the laws of the jurisdiction within which the Unit is located, and the courts having jurisdiction with respect to matters relating to this Agreement shall be the courts of that jurisdiction.

8.9 Notices hereunder shall be delivered and deemed received in accordance with the procedures set out in the Unit Operating Agreement.

8.10 Each of the parties shall from time to time and at all times do all such further acts and execute and deliver all further deeds and documents as shall be reasonably required in order fully to perform and carry out the terms of this Agreement. 
IN WITNESS WHEREOF the parties have executed this Agreement effective as of the date and year first above written.

[PARTY]

Per:

Per:

[PARTY]

Per:

Per:

\section{PETROLEUM JOINT VENTURE ASSOCIATION GAS BALANCING AGREEMENT}

Note: This draft Gas Balancing Agreement has been prepared for lands subject to a 1971, 1974 or 1981 CAPL Operating Procedure, and is appropriate for situations in which there is common ownership of production from the lands under this Agreement, and such lands are subject to a common royalty rate.

\section{GUIDELINE AGREEMENT (CAPL OPERATING PROCEDURE)} 19

THIS AGREEMENT made effective the day of

BETWEEN (AMONG):

[DESCRIBE PARTY] (herein called “

OF THE FIRST PART ")

$$
\text { - and - }
$$

[DESCRIBE PARTY] (herein called “

OF THE SECOND PART

$$
\text { - and - }
$$

\section{[ADD ADDITIONAL PARTIES AS NECESSARY]}

WHEREAS and are Joint-Operators under the Canadian Association of Petroleum Landmen Operating Procedure attached to the [describe the agreement under which the CAPL Operating Procedure is made applicable to the Lands] (the "Operating Procedure");

AND WHEREAS the Operating Procedure governs operations on the Lands; 
AND WHEREAS each Joint-Operator has made (or will make) arrangements to sell or utilize the share of the Gas produced from the Lands attributable to such Joint-Operator's participating interest;

AND WHEREAS it appears that such arrangements of the Joint-Operators may allow commencing delivery at different times or be limited from time to time;

AND WHEREAS the Joint-Operators desire the flexibility to permit the taking of Gas from the Lands on a disproportionate basis from time to time;

NOW THEREFORE THIS AGREEMENT WITNESSES THAT the parties hereto have agreed as follows:

\section{ARTICLE I}

\section{DEFINITIONS}

1.1 In this Agreement, except as specifically provided for herein, terms defined in the Operating Procedure shall have the same meaning herein.

\subsection{In this Agreement:}

(a) "Gas" means that portion of Raw Gas production from the Lands, delivered at the outlet of the Plant, that remains after being processed at the Plant and which is composed essentially of methane, but excludes such portion as is lost in processing or consumed as fuel;

(b) "Inlet Volume" in any month means the volume of Raw Gas allocated to a Joint-Operator as its share of Raw Gas entering the Plant during that month as determined in accordance with this Agreement;

(c) "Lands" means [describe the lands which are to be subject to this Agreement; if all of the lands subject to the Operating Procedure are to be subject to this Agreement, then this defined term can be deleted and replaced with the term "joint lands" throughout the Agreement]"

(d) "Net Price" means the price received for Gas sold on an arms-length basis at the outlet of the Plant by an Overproduced Party on a volume weighted average basis for the 12 month period in which such party took Gas preceding the last month of sales by such party, or the fair market value at the time of liquidation under Section 6.1 of Gas taken by an Overproduced Party for such party's own use or sale to an affiliate, less:

(i) lessor royalties paid during such period;

(ii) operating costs, other than those costs of the type described in Section 4.5, charged to such party in accordance with the terms hereof and the terms of the Operating Procedure during such period; and

(iii) production and royalty taxes paid during period in respect of such production;

(e) "Overproduced Party" means a party who has sold more than its Working Interest Share of Gas produced from the Lands; 
(f) "Plant" means the natural gas processing facility where production from the Lands is processed, located at

(g) "Raw Gas" means natural gas (which may include hydrocarbon liquids, water and other constituents) produced from the Lands and which has not been processed at the Plant;

(h) "Recovery Volume" has the meaning set out in Section 3.1;

(i) "Remaining Reserves" means the total remaining recoverable Gas reserves from the Lands as established or redetermined from time to time in accordance with Section 5.2;

(j) "Sales Volume" in any month means the volume of Gas which a JointOperator's Gas purchaser has requested and purchased for that month;

(k) "Shrinkage Volume" in any month means the volume of Raw Gas allocated to a Joint-Operator as its Working Interest Share of shrinkage gas resulting from the operation of the Plant during that month;

(l) "Underproduced Party" means a party who has sold less than its Working Interest Share of Gas produced from the Lands; and

(m) "Working Interest Share" means the participating interest of a Joint-Operator in the Lands.

\section{ARTICLE II}

\section{ALLOCATION OF SALES VOLUMES}

2.1 Each Joint-Operator shall be entitled to take its Working Interest Share of total production of Raw Gas from the Lands or up to its entitlement as described in Section 3.1 herein. If the Sales Volume of a party is less than its Working Interest Share, the excess volumes shall be allocated to those parties with Sales Volumes in excess of their Working Interest Share of total production pro rata in proportion to the respective Working Interest Shares of such parties. Any imbalances between a party's Working Interest Share and actual allocated sales shall be recorded by the Operator, converted to heat content values, and a statement of cumulative over and under production, on a heat content basis, shall be furnished with the monthly allocation statements.

2.2 All natural gas liquids and Plant products other than Gas which are sold or otherwise disposed of shall be allocated to the parties based on their respective Working Interest Shares. All Shrinkage Volumes shall be allocated based on each party's Working Interest Share. Each party's Inlet Volume shall be equal to the sum of its Sales Volume and Shrinkage Volume.

\section{ARTICLE III}

\section{RECOVERED BY UNDERPRODUCED PARTY}

3.1 In addition to any recovery of underproduction that may occur under Section 2.1, an Underproduced Party must give at least 30 days notice to all JointOperators of its intention to commence recovery of underproduction by taking 
volumes in excess of its Working Interest Share. After giving such notice and if not precluded by any other terms in this Agreement, an Underproduced Party shall be entitled to take, in addition to its Working Interest Share, a volume of Gas (the "Recovery Volume") up to $50 \%$ of the total Working Interest Shares of Overproduced Parties.

3.2 If two or more Underproduced Parties, pursuant to Section 3.1 above, are recovering underproduction at the same time, allocation of Recovery Volumes shall be based on the ratios of the cumulative underproductions of the Underproduced Parties. The Recovery Volumes taken from the Working Interest Shares of Overproduced Parties shall be apportioned based on the ratios of the cumulative overproductions of Overproduced Parties.

3.3 Each Joint-Operator shall have the right to deliver to its Gas purchaser its full Working Interest Share of the maximum or allowable Gas production to meet a deliverability test by such purchaser, provided that such party shall first provide notice to the Operator and all other parties of its requirement for the Gas. A party cannot exercise its rights under this Section 3.3 for a cumulative period in excess of two months in each year.

\section{ARTICLE IV}

\section{RESPONSIBILITIES OF PARTIES}

4.1 The Operator shall have the duty of controlling Gas production and the responsibility for administering the provisions of this Agreement. The reasonable and good faith determinations of Operator in performing its duties and responsibilities shall be binding on the parties and the Operator, in its capacity as Operator, shall not incur any liability to any party except for loss or damage resulting from its gross negligence or wilful misconduct or that of its agents and employees.

4.2 For purposes of determining obligations to pay lessor royalties, each party taking more than its Working Interest Share of Gas for any month shall be deemed to have taken a portion of the Gas not taken by each party taking less than its Working Interest Share equal to such overtaking party's share of the total overproduction for the month. Other provisions contained in the Operating Procedure notwithstanding, each party taking more than its Working Interest Share of Gas shall be responsible for the payment of all lessor royalties thereon. Each overtaking party shall pay to the undertaking parties the share of such Lessor royalties which the undertaking parties would otherwise be obliged to pay had this Agreement not been entered into, such payment shall be made at least three days prior to the royalty payment date established by the title documents in question. Each party hereto taking less than its Working Interest Share at any time hereby indemnifies the other parties hereto against the claims, demands and causes of action which have as their basis an alleged entitlement to payment in excess of that received from the party taking the Gas, or which may be brought by lessors to whom such indemnitor is obligated under the title documents. 
4.3 All royalties (except lessor royalties), overriding royalties and other burdens applicable to each party's Working Interest Share in Gas production shall be paid by the parties responsible therefor. Each party indemnifies all other parties hereto against any claim by, or liability to, any owner of royalties (except lessor royalties) or other interests in Gas production burdening its Working Interest Share regardless of such party's capability to utilize or sell its Working Interest Share of Gas. The parties shall provide to each other such information as may be required in order to determine payments required to holders of royalties (except lessor royalties) and other burdens.

\subsection{Each party taking Gas shall pay any and all production taxes due on such Gas.}

4.5 Field expenses, which shall include but are not limited to surface rentals, lease maintenance, access roads, workovers, and other costs that do not vary with the volume of production, and which shall exclude costs of the type described in Section 4.6, shall be charged to parties based on their respective Working Interest Shares.

4.6 Costs attributed to dehydration, gathering and processing, and other costs that vary with the volume of production, shall be charged based on Inlet Volumes as determined pursuant to Section 2.2.

\section{ARTICLE V}

\section{LIMIT TO OVERPRODUCTION}

5.1 Notwithstanding Section 3.3, no party shall take Gas after such party's cumulative overproduction of Gas taken equals the product of $75 \%$ of such party's Working Interest Share and the Remaining Reserves.

5.2 The parties agree that the Remaining Reserves as at $19 \_10^{3} \mathrm{~m}^{3}$. Any party can request that the Operator redetermine the Remaining Reserves provided that the Operator shall not be required to redetermine the Remaining Reserves more than once per year. The Operator shall request written approval of the parties for its redetermination of the Remaining Reserves. If the Operator does not receive within one month after delivery of its request, the written approval of two or more parties having an aggregate participating interest of $\%$ for the redetermination of the Remaining Reserves, the Operator shall commission an independent third party chosen by the Operator to redetermine the Remaining Reserves. The independent third party's evaluation shall be binding on all parties. The cost of the third party's evaluation is to be charged to the joint account and borne by all parties in proportion to their Working Interest Shares.

5.3 If an Overproduced Party has ceased production because such party's cumulative overproduction of Gas taken equals the product of such party's Working Interest Share and the Remaining Reserves, the Overproduced Party may resume production if the most recent reserve determination shows greater reserves than the previous reserve determination. 


\section{ARTICLE VI}

\section{LIQUIDATION OF GAS IMBALANCES}

6.1 If at the end of the fifth year of this Agreement, or when production from the Lands has permanently ceased as determined by the Operator (whichever first occurs), and there exists at that time a production imbalance, the settlement due to the Underproduced Parties shall be determined and settled in the following manner:

(a) each Overproduced Party shall contribute to a liquidation pool established by the Operator a sum of money equal to the product of such party's volume of overproduction and such party's Net Price; and

(b) the Operator shall distribute the liquidation pool proceeds to the Underproduced Parties in accordance with the ratio of their respective underproduction.

6.2 The Operator shall be responsible for the determination of over and under production and the amounts to be contributed to or withdrawn from the liquidation pool by each party. The Operator shall receive and promptly distribute the liquidation pool funds, and such funds shall be kept in a segregated trust account. The Operator shall prepare invoices for the Overproduced Parties within 60 days after the Operator has determined that production from the Lands has permanently ceased. Parties required to contribute to the liquidation pool shall do so within 30 days of receiving an invoice from the Operator for their contribution. The Overproduced Parties shall provide such information as may be reasonably required by the Operator in order to permit the Operator to calculate the Net Price.

6.3 The Operator shall not be liable to Underproduced Parties in its capacity as Operator for any deficiency in the liquidation pool if an Overproduced Party does not contribute its required moneys to the liquidation pool.

6.4 For the purpose of calculating the Net Price of an Overproduced Party, an Underproduced Party may dispute the gross price for Gas sold or used by the Overproduced Party if the Gas sold by such party during the relevant 12 month period was sold to an Affiliate of the Overproduced Party or utilized by the Overproduced Party without a sale thereof. If the parties cannot agree on a fair market value price for such Gas, then the determination of such fair market value price shall be referred to an arbitrator pursuant to the Arbitration Act. The costs of such arbitration shall be borne by the Underproduced Party or Parties which disputed the gross price used by the Overproduced Parties.

6.5 If the title of a party to the Lands should fail or be surrendered, then:

(a) if that party is an Overproduced Party, it shall immediately settle its overproduction balance in the manner set out in Section 6.1 above, mutatis mutandis; or

(b) if that party is an Underproduced Party, then it shall no longer have any right to recover its underproduction balance until settlement occurs in accordance with Section 6.1 above. 


\section{ARTICLE VII}

\section{TERM}

7.1 This Agreement shall be effective as of the date first above written, and unless extended in writing by the parties, shall terminate upon the earlier of the end of the fifth year of this Agreement or the permanent cessation of production from the Lands as determined by the Operator; provided that the obligations of the parties under Article VI shall continue after termination.

\section{ARTICLE VIII}

\section{MISCELLANEOUS}

8.1 This Agreement is binding upon the Joint-Operators and their respective successors and permitted assigns.

8.2 No party may assign its interest in the Lands or in this Agreement without the prior written consent of the other parties hereto.

8.3 Each party hereby indemnifies and agrees to defend the other parties against all liability for claims which may be asserted by third parties under any contract, whether now or hereafter existing, between said third party and such indemnifying party and arising out of the operation of this Agreement or activities of any party under its provisions, and further agrees to save the other parties harmless from all judgements or damages sustained and costs incurred in connection therewith.

8.4 This Agreement supersedes the provisions of Clauses 501, 602, 603, 604, 605,2401 and 2402 of the Operating Procedure.

8.5 Article headings and any other headings or captions or index hereto shall not be used in any way in construing or interpreting any provision hereof.

8.6 Unless otherwise expressly stated, whenever the singular or masculine or neuter is used in this Agreement, the same shall be construed as meaning plural or feminine or body politic or corporate or vice versa, as the context so requires.

8.7 No amendments or variation of this Agreement shall be binding upon any party unless it is evidenced in writing, executed by all of the parties.

8.8 This Agreement shall for all purposes be construed and interpreted according to the laws of the jurisdiction within which the Lands is located, and the courts having jurisdiction with respect to matters relating to this Agreement shall be the courts of that jurisdiction.

8.9 Notices hereunder shall be delivered and deemed received in accordance with the procedures set out in the Operating Procedure. 
8.10 Each of the parties shall from time to time and at all times do all such further acts and execute and deliver all further deeds and documents as shall be reasonably required in order fully to perform and carry out the terms of this Agreement.

IN WITNESS WHEREOF the parties have executed this Agreement effective as of the date and year first above written.

\section{[PARTY]}

Per:

Per:

[PARTY]

Per:

Per:

[ADD ADDITIONAL PARTIES IF NECESSARY] 